\title{
Structure, Morphology, Heat Capacity, and Electrical Transport Properties of $\mathrm{Ti}_{3}(\mathrm{Al}, \mathrm{Si}) \mathrm{C}_{2}$ Materials
}

\author{
Kamil Goc ${ }^{1, *}{ }^{\oplus}$, Janusz Przewoźnik ${ }^{1}(0)$, Katarzyna Witulska ${ }^{2}$, Leszek Chlubny ${ }^{2}$, Waldemar Tokarz ${ }^{1}$, \\ Tomasz Strączek $^{1}$, Jan Marek Michalik ${ }^{1}{ }^{1}$, Jakub Jurczyk ${ }^{1,3}$, Ivo Utke ${ }^{3}{ }^{\mathbb{D}}$, Jerzy Lis ${ }^{2}$ and Czesław Kapusta ${ }^{1}$ \\ 1 Faculty of Physics and Applied Computer Science, AGH University of Science and Technology, \\ Al. Mickiewicza 30, 30-059 Kraków, Poland; januszp@agh.edu.pl (J.P.); tokarz@agh.edu.pl (W.T.); \\ Tomasz.Straczek@agh.edu.pl (T.S.); jmichali@agh.edu.pl (J.M.M.); Jakub.Jurczyk@agh.edu.pl (J.J.); \\ kapusta@agh.edu.pl (C.K.) \\ 2 Faculty of Materials Science and Ceramics, AGH University of Science and Technology, Al. Mickiewicza 30, \\ 30-059 Kraków, Poland; chabior@agh.edu.pl (K.W.); leszek@agh.edu.pl (L.C.); lis@agh.edu.pl (J.L.) \\ 3 Laboratory for Mechanics of Materials and Nanostructures, Empa-Swiss Federal Laboratories for Materials \\ Science and Technology, Feuerwerkerstrasse 39, 3602 Thun, Switzerland; ivo.utke@empa.ch \\ * Correspondence: Kamil.Goc@fis.agh.edu.pl
}

check for updates

Citation: Goc, K.; Przewoźnik, J.; Witulska, K.; Chlubny, L.; Tokarz, W.; Strączek, T.; Michalik, J.M.; Jurczyk, J.; Utke, I.; Lis, J.; et al. Structure, Morphology, Heat Capacity, and Electrical Transport Properties of $\mathrm{Ti}_{3}(\mathrm{Al}, \mathrm{Si}) \mathrm{C}_{2}$ Materials. Materials 2021, 14, 3222. https://doi.org/10.3390/ ma14123222

Academic Editor: Alexander A. Gromov

Received: 8 April 2021

Accepted: 6 June 2021

Published: 11 June 2021

Publisher's Note: MDPI stays neutral with regard to jurisdictional claims in published maps and institutional affiliations.

Copyright: (c) 2021 by the authors. Licensee MDPI, Basel, Switzerland. This article is an open access article distributed under the terms and conditions of the Creative Commons Attribution (CC BY) license (https:/ / creativecommons.org/licenses/by/ $4.0 /)$.
Abstract: A study of $\mathrm{Ti}_{3} \mathrm{Al}_{1-x} \mathrm{Si}_{x} \mathrm{C}_{2}(x=0$ to $x=1) \mathrm{MAX}$-phase alloys is reported. The materials were obtained from mixtures of $\mathrm{Ti}_{3} \mathrm{AlC}_{2}$ and $\mathrm{Ti}_{3} \mathrm{SiC}_{2}$ powders with hot pressing sintering technique. They were characterised with $\mathrm{X}$-ray diffraction, heat capacity, electrical resistivity, and magnetoresistance measurements. The results show a good quality crystal structure and metallic properties with high residual resistivity. The resistivity weakly varies with $\mathrm{Si}$ doping and shows a small, positive magnetoresistance effect. The magnetoresistance exhibits a quadratic dependence on the magnetic field, which indicates a dominant contribution from open electronic orbits. The Debye temperatures and Sommerfeld coefficient values derived from specific heat data show slight variations with $\mathrm{Si}$ content, with decreasing tendency for the former and an increase for the latter. Experimental results were supported by band structure calculations whose results are consistent with the experiment concerning specific heat, resistivity, and magnetoresistance measurements. In particular, they reveal that of the s-electrons at the Fermi level, those of Al and Si have prevailing density of states and, thus predominantly contribute to the metallic conductivity. This also shows that the high residual resistivity of the materials studied is an intrinsic effect, not due to defects of the crystal structure.

Keywords: MAX phases; hot pressing synthesis; heat capacity; electrical properties; magnetoresistance; DOS calculations

\section{Introduction}

MAX phases belong to the ternary and quaternary group of materials (carbides and nitrides). They can be specified by the main formula $M_{n+1} A X_{n}$, where $M$ is an early transition metal, A stands for an A-group element ( $\mathrm{Al}, \mathrm{Si})$, and $\mathrm{X}$ is carbon and/or nitrogen. These compounds crystallize in the hexagonal system $\mathrm{P} 6_{3} / \mathrm{mmc}$ and they possess a nanolaminated structure with coexisting different types of bonds between elements. As a result of their heterodesmic structure, some properties of MAX phases, like high thermal and electrical conductivity, as well as a ductile nature, derive from metals. On the other hand, they can behave as typical ceramics, e.g., they have high stiffness, low thermal expansion coefficient, and perfect thermal and chemical resistance, even at high temperatures. Owing to this combination of untypical properties, MAX phases are located between ceramic and metallic materials [1-4]. Their properties make them useful in applications like conductive coatings, heat proof materials, thermal shock resistant composites, and neutron irradiation resistive systems $[1,5,6]$.

The unit cell of these materials is built of $\mathrm{M}_{6} \mathrm{X}$ octahedrons, which are located between A-atom layers and the atoms of carbon/nitrogen occupying the centers of octahedrons. 
Referring to the main formula $\mathrm{M}_{n+1} \mathrm{AX}_{n}$, where $n=1,2,3, \ldots$, different types of MAX phases are labelled as 211,312 and 413 , respectively. It means that there are two M-layers separating the A-layers in the 211 group, whereas in 312s there are three and in 413s, there are four M-layers. According to the literature, ordered structures with $n=4,5,6$ and even 7, creating 514, 615 and 716 MAX phases have also been discovered. A number of papers report on several methods, which can be used to obtain them as bulk materials. They include hot isostatic pressing [7-9], microwave sintering [10], arc melting [11,12], annealing [13] spark plasma sintering [14-17], and self-propagating high-temperature synthesis (SHS) [18-24], usually followed by hot pressing sintering [18,22,25]. To obtain them in the form of thin films, physical or chemical vapour-deposition (PVD or CVD) can be used $[2,12,26]$.

Previous studies have shown that in these compounds many substitutions on $\mathrm{M}, \mathrm{A}$, and $\mathrm{X}$ position are possible. Doping elements usually come from the neighbourhood in the periodic table, due to their close atomic radii and electronic similarity. About 100 sets of compounds of solid solutions, like $\mathrm{Cr}_{2}\left(\mathrm{Al}_{1-x} \mathrm{Si}_{x}\right) \mathrm{C}$, $\mathrm{Ti}_{3}\left(\mathrm{Al}_{x} \mathrm{Sn}_{1-x}\right) \mathrm{C}_{2}, \mathrm{Ti}_{2} \mathrm{Al}\left(\mathrm{C}_{0.5} \mathrm{~N}_{0.5}\right)$, $\mathrm{Ti}_{3}\left(\mathrm{Al}_{0.75} \mathrm{Si}_{0.25}\right) \mathrm{C}_{2}$ and others have been fabricated and examined so far. Moreover, solid solutions of MAX phases often present more attractive physical, chemical, and mechanical properties compared to the end-member materials [7,27-32].

At present, the most investigated pure MAX phases, belonging to the 312 family (Figure 1), are $\mathrm{Ti}_{3} \mathrm{AlC}_{2}$ and $\mathrm{Ti}_{3} \mathrm{SiC}_{2}$. Consequently, the next step of MAX phases development was to synthesize and investigate solid solution-materials in the Ti-Al-Si-C system. Usually, the $\mathrm{Ti}_{3}\left(\mathrm{Al}_{1-x} \mathrm{Si}_{x}\right) \mathrm{C}_{2}$ compounds are synthesized from pure elemental powders with different stoichiometry $x$ [31]. Following our recent work on $\mathrm{Ti}_{3} \mathrm{AlC}_{2}$ material [19], in this paper, we present results on the synthesis and characterization of three different $\mathrm{Ti}_{3}\left(\mathrm{Al}_{1-x} \mathrm{Si}_{x}\right) \mathrm{C}_{2}$ materials with stoichiometry $x=1 / 3,1 / 2$ and $2 / 3$.

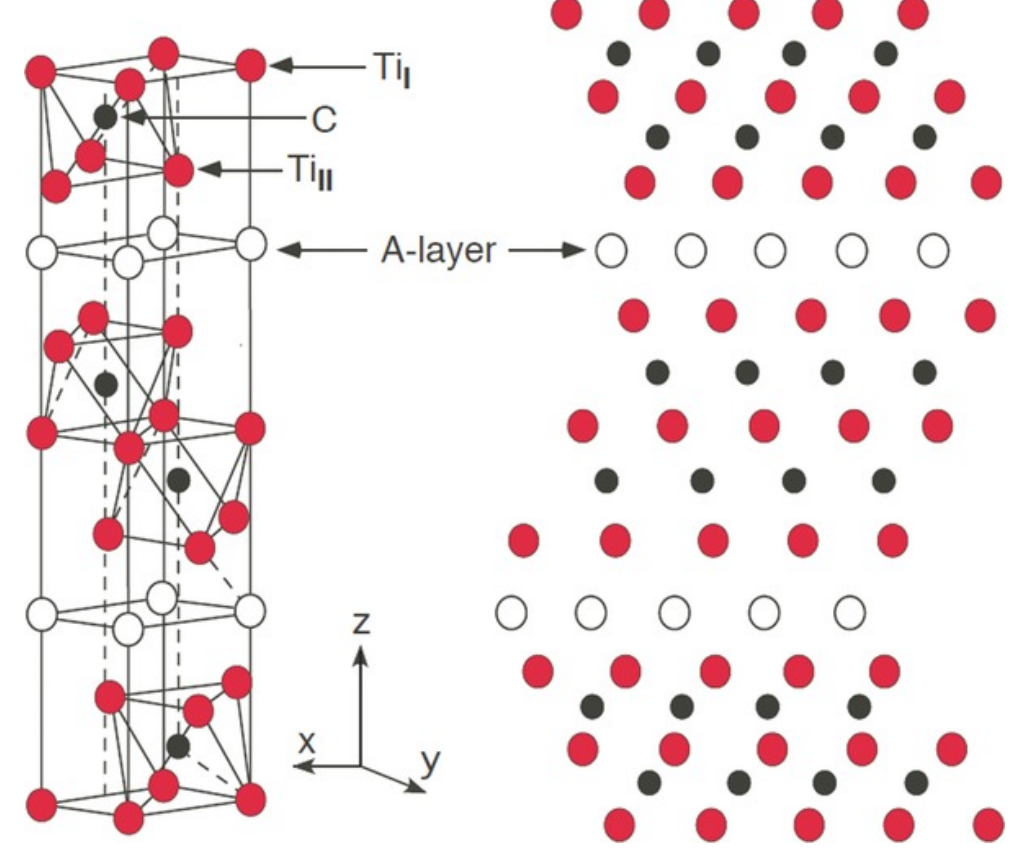

Figure 1. Crystal structure of a $312 \mathrm{MAX}$ phase. Ti atoms occupy two different sites, $\mathrm{Ti}_{\mathrm{I}}$ and $\mathrm{Ti}_{\mathrm{II}}$. A layer of A-group atoms appears after each third Ti layer [33].

The mixed compounds prepared within the present work have been produced by hot pressing synthesis from the $\mathrm{Ti}_{3} \mathrm{AlC}_{2}$ and $\mathrm{Ti}_{3} \mathrm{SiC}_{2}$ powders. Hot-Pressing (HP) is a method in which high temperature and uniaxial pressing are applied simultaneously to the powder in order to obtain dense material. The two starting materials have been synthesized by SHS from the appropriate mixture of the $\mathrm{TiAl}, \mathrm{Ti}, \mathrm{Si}$, and $\mathrm{C}$ powder components. For the 
dense materials of MAX phase compounds obtained, the X-ray diffraction (XRD), scanning electron microscopy (SEM), heat capacity, and electrical resistivity/magnetoresistance measurements have been carried out. The experimental characterization has been supported with calculations of the local densities of electronic states.

From the XRD patterns, the crystal structure parameters of the compounds have been determined. SEM and energy dispersive X-ray spectroscopy (EDS) analysis have been used for the evaluation of the microstructure and the elements concentration. A specific heat study was carried out to obtain information on the contributions of the electronic and the lattice subsystems. Measurements of the electrical resistance and magnetoresistance in the temperature range $4-300 \mathrm{~K}$ and at the magnetic field up to 9 Tesla were done to get the information on the type of the electrical conductivity and the mobility of the carriers. The results of measurements are discussed with respect to the local density of states calculations. The relation to the thermal and electrical properties of the materials studied is analysed and discussed.

\section{Experimental}

For the synthesis of the $\mathrm{Ti}_{3}\left(\mathrm{Al}_{1-x} \mathrm{Si}_{x}\right) \mathrm{C}_{2}$, mixtures of SHS derived powders of $\mathrm{Ti}_{3} \mathrm{AlC}_{2}$ and $\mathrm{Ti}_{3} \mathrm{SiC}_{2}$ were used, according to the intended stoichiometry, as follows:

$$
\begin{aligned}
& { }^{2}{ }_{3} \mathrm{Ti}_{3} \mathrm{AlC}_{2}+{ }^{1 / 3} \mathrm{Ti}_{3} \mathrm{SiC}_{2} \rightarrow \mathrm{Ti}_{3} \mathrm{Al}_{2 / 3} \mathrm{Si}_{1 / 3} \mathrm{C}_{2} \\
& 1 / 2 \mathrm{Ti}_{3} \mathrm{AlC}_{2}+{ }^{1 / 2} \mathrm{Ti}_{3} \mathrm{SiC}_{2} \rightarrow \mathrm{Ti}_{3} \mathrm{Al}_{1 / 2} \mathrm{Si}_{1 / 2} \mathrm{C}_{2} \\
& 1 / 3 \mathrm{Ti}_{3} \mathrm{AlC}_{2}+{ }^{2} / 3 \mathrm{Ti}_{3} \mathrm{SiC}_{2} \rightarrow \mathrm{Ti}_{3} \mathrm{Al}_{1 / 3} \mathrm{Si}_{2 / 3} \mathrm{C}_{2}
\end{aligned}
$$

All the mixtures (6 g each) were homogenized in a ball-mill (Gabrielli, Calenzano, Italy) with tungsten carbide balls for $24 \mathrm{~h}$. After that, the homogenized mixtures were placed in a 1-inch diameter graphite mould and subjected to the hot-pressing process. Samples stayed in the hot pressing (HP) apparatus for $1 \mathrm{~h}$ at maximum temperature and pressure, $1300{ }^{\circ} \mathrm{C}$ and $25 \mathrm{MPa}$, respectively. After completion of the reactive pressing process, the graphite residues were removed from the samples surface.

In order to determine the phase composition of both, starting powders and hot-pressed bulk materials, the XRD measurements were carried out at room temperature in BraggBrentano geometry using $\mathrm{Cu} \mathrm{K} \mathrm{K}_{\alpha}$ radiation. The Siemens D5000 diffractometer (Siemens AG, Berlin, Germany) equipped with a diffracted beam graphite monochromator (using zero background sample holder) was used for the powders and the Panalytical Empyrean diffractometer was used for the bulk samples. Mass contributions of the respective phases were derived according to Rietveld analysis [34]. Electrical resistivity, magnetoresistance, and heat capacity measurements were carried out, respectively, with the AC transport and heat capacity options of a Physical Property Measurement System, PPMS (Quantum Design, San Diego, CA, USA) apparatus. The samples for the electrical resistivity and magnetoresistance measurements were cut from the pellets with a diamond saw to obtain parallelepipeds $(1 \mathrm{~mm} \times 1 \mathrm{~mm} \times 10 \mathrm{~mm}$ ), with their longest edge parallel to the pellet plane. The density of states calculations were done with Wien2K software (version 14) [35], which is suitable for periodic structures as it uses periodic boundary conditions. SEM secondary electron images were taken on a JEOL 5900LV microscope (JEOL Ltd, Tokyo, Japan) and the EDS analysis was performed using the Noran type 6 equipment (Thermo Fisher Scientific, Waltham, MA, USA).

\section{Characterization}

\subsection{Characterization of the Crystallographic Structure}

The Rietveld analysis of the XRD powder patterns for the starting $\mathrm{Ti}_{3} \mathrm{AlC}_{2}$ and $\mathrm{Ti}_{3} \mathrm{SiC}_{2}$ materials revealed some admixtures of impurity phases; see Figure 2 . In the case of $\mathrm{Ti}_{3} \mathrm{AlC}_{2}$ material, the $12.3 \pm 0.7 \%$ mass contribution of a secondary TiC cubic phase with unit cell parameter $a=4.3219 \pm 0.0002 \AA$ was found. The analysis of the XRD powder pattern of $\mathrm{Ti}_{3} \mathrm{SiC}_{2}$ material revealed $26.5 \pm 1.2 \%$ contribution of the $\mathrm{TiC}$ phase and $11.5 \pm 1.0 \%$ 
contribution of the $\mathrm{TiSi}_{2}$ phase with orthorhombic (space group $F d d d$ ) unit cell, with $a=8.260 \pm 0.002 \AA, b=4.800 \pm 0.001 \AA$ and $c=8.549 \pm 0.003 \AA$.

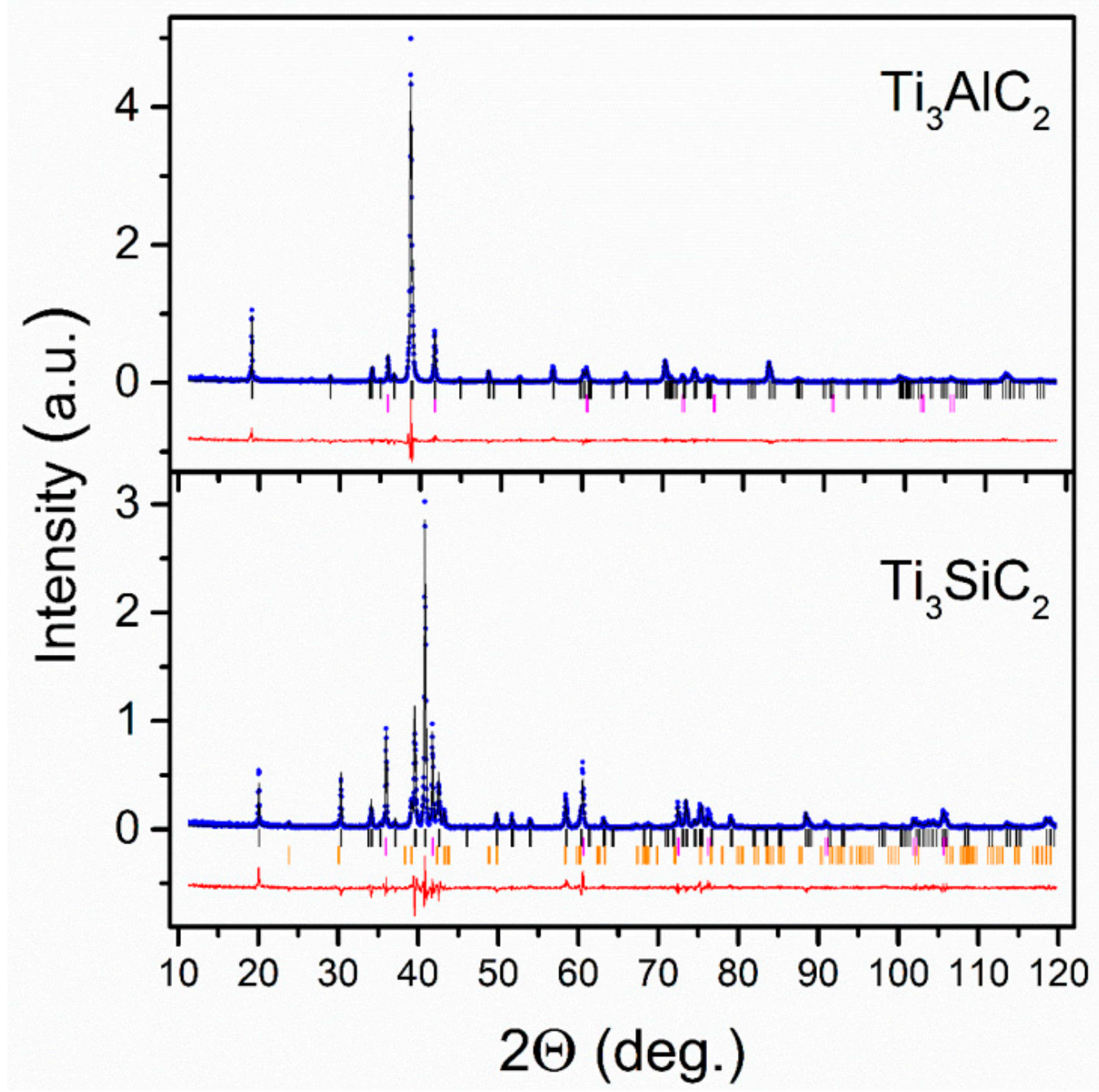

Figure 2. XRD patterns (blue dots) and the best-fit Rietveld refinement (solid black lines) of the $\mathrm{Ti}_{3} \mathrm{AlC}_{2}$ and $\mathrm{Ti}_{3} \mathrm{SiC}_{2}$ starting materials. The rows of vertical bars denote the Bragg peak positions for the corresponding MAX phase (black), TiC (magenta), and $\mathrm{TiSi}_{2}$ (orange). The solid red line represents the difference between the experimental and calculated patterns.

The XRD patterns, along with the Rietveld refined curves for the HP synthesized $\mathrm{Ti}_{3}\left(\mathrm{Al}_{1-x} \mathrm{Si}_{x}\right) \mathrm{C}_{2}$ bulk samples, are presented in Figure 3. It has to be noted that in all patterns, besides the MAX phase, the impurity $\mathrm{TiC}$ and $\mathrm{Al}_{2} \mathrm{O}_{3}$ (corundum) with trigonal (space group $R \overline{3} c$ ) phases were also detected.

The calculated mass contributions of the phases are collected in Table 1 and the structural data corresponding to the majority $\mathrm{Ti}_{3}\left(\mathrm{Al}_{1-x} \mathrm{Si}_{x}\right) \mathrm{C}_{2}$ hexagonal phases are listed in Table 2. Materials contain about $90 \%$ of MAX phase and it can be noticed that this is slightly higher than for the starting materials, indicating that during the hot pressing process, the $\mathrm{TiC}$ and $\mathrm{TiSi}_{2}$ impurities convert into the MAX phase. A similar effect was observed in our previous study [19]. Narrow lines of XRD patterns reveal their good crystallinity. Spurious phases present in the amount less than 10\% in the samples of solid solution materials, which are mainly $\mathrm{TiC}$, do not influence significantly the stoichiometry and properties of the main MAX phase. 


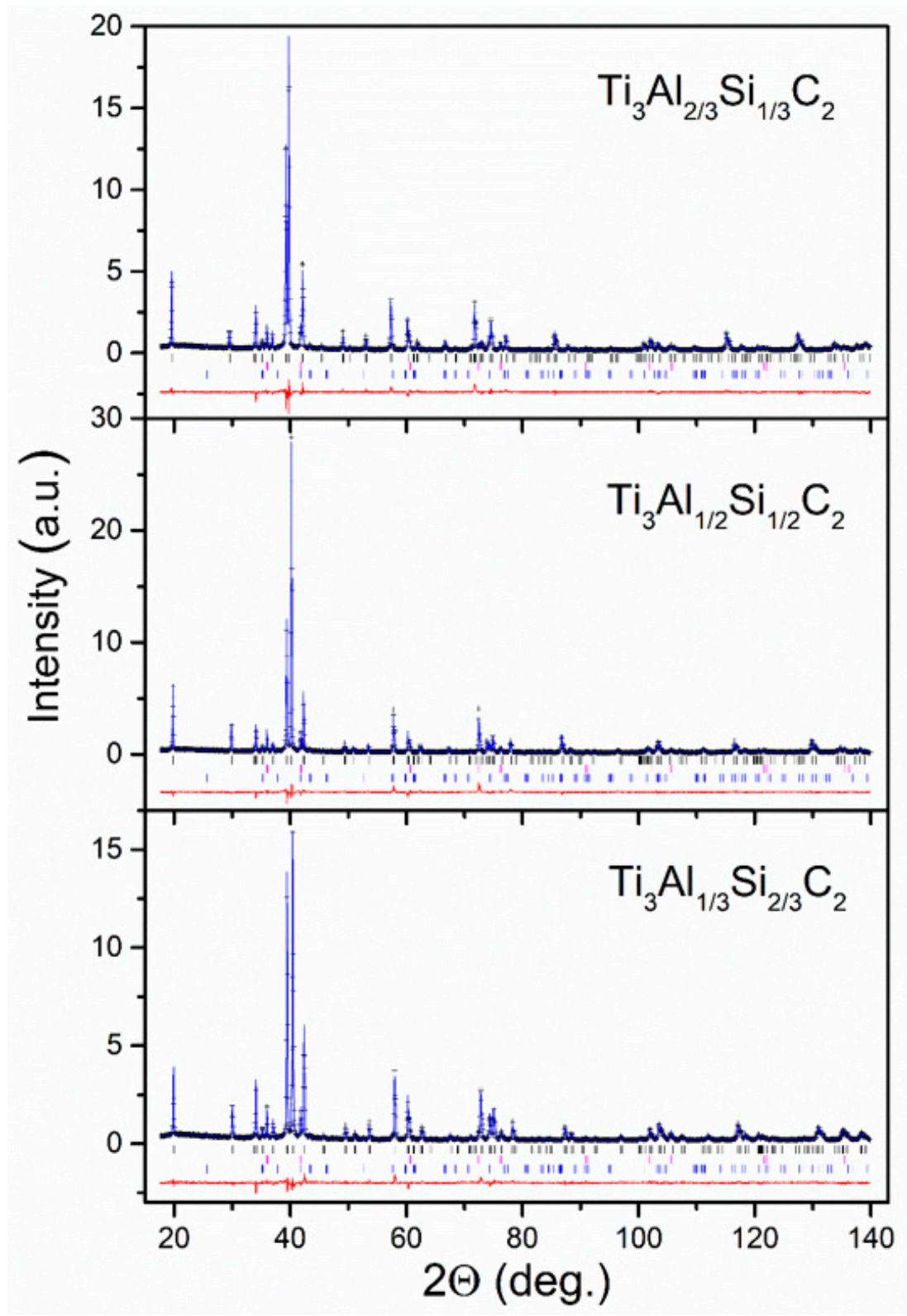

Figure 3. XRD patterns (black crosses) and the best-fit Rietveld refinement (solid blue lines) of the $\mathrm{Ti}_{3} \mathrm{Al}_{1-x} \mathrm{Si}_{x} \mathrm{C}_{2}$ bulk sample (pellet). The rows of vertical bars below denote the Bragg peak positions for corresponding MAX phase (black), TiC (magenta), and $\mathrm{Al}_{2} \mathrm{O}_{3}$ (blue) phases. The solid red lines represent the difference between the experimental and calculated patterns.

Table 1. Mass contributions (\%) of the phases obtained from the analysis of $\mathrm{X}$-ray diffraction patterns of $\mathrm{Ti}_{3}\left(\mathrm{Al}_{1-x} \mathrm{Si}_{x}\right) \mathrm{C}_{2}$ bulk samples with $x=0,1 / 3,1 / 2,2 / 3$, where $\mathrm{Ti}_{3}\left(\mathrm{Al}_{1-x} \mathrm{Si}_{x}\right) \mathrm{C}_{2}$ is the majority hexagonal (space group $\mathrm{P} 6_{3} / \mathrm{mmc}$ ) phase and $\mathrm{TiC}$ cubic (space group $\mathrm{F} \mathrm{m} \overline{3} \mathrm{~m}$ ) and $\mathrm{Al}_{2} \mathrm{O}_{3}$ trigonal (space group $\mathrm{R} \overline{\mathrm{3}} \mathrm{c}$ ) are secondary phases.

\begin{tabular}{ccccc}
\hline$x$ (Si at. $\%)$ & $\mathbf{T i}_{\mathbf{3}}\left(\mathbf{A l} \mathbf{1}_{\mathbf{1}-\boldsymbol{x}} \mathbf{S i}_{\boldsymbol{x}}\right) \mathbf{C}_{\mathbf{2}}$ & $\mathbf{T i C}$ & $\mathbf{A l}_{\mathbf{2}} \mathbf{O}_{\mathbf{3}}$ & $\mathbf{T i S i}_{\mathbf{2}}$ \\
\hline 0 & $88(3)$ & $12.3(7)$ & 0 & - \\
\hline $1 / 3$ & $89(2)$ & $6(1)$ & $5(1)$ & 0 \\
\hline $1 / 2$ & $87(2)$ & $8(1)$ & $3(1)$ & 0 \\
\hline $2 / 3$ & $91(2)$ & $6(2)$ & $3(1)$ & 0 \\
\hline 1 & $62(3)$ & $27(2)$ & - & $11(1)$ \\
\hline
\end{tabular}


Table 2. Structural data of the dominant $\mathrm{Ti}_{3}\left(\mathrm{Al}_{1-x} \mathrm{Si}_{x}\right) \mathrm{C}_{2}$ hexagonal phase (space group P $6_{3} / \mathrm{mmc}$ ) obtained from the Rietveld analysis of $\mathrm{X}$-ray diffraction patterns of $\mathrm{Ti}_{3}\left(\mathrm{Al}_{1-x} \mathrm{Si}_{x}\right) \mathrm{C}_{2}$ bulk samples with $x=0,0.33,0.5,0.67$ and $1: a, c$-hexagonal unit cell parameters, $z_{T i}, z_{C}$-positional parameters for $\mathrm{Ti}(4 \mathrm{f})$ and $\mathrm{C}(4 \mathrm{f})$ sites, respectively.

\begin{tabular}{ccccc}
\hline$x$ (Si at.) & $\boldsymbol{a}(\AA)$ & $c(\AA)$ & $z_{T i}$ & $z_{C}$ \\
\hline 0 & $3.0746(2)$ & $18.5670(6)$ & $0.1273(3)$ & $0.5692(8)$ \\
\hline $1 / 3$ & $3.0736(1)$ & $18.1500(3)$ & $0.1310(2)$ & $0.5720(5)$ \\
\hline $1 / 2$ & $3.0718(1)$ & $17.9511(3)$ & $0.1326(2)$ & $0.5711(5)$ \\
\hline $2 / 3$ & $3.0713(1)$ & $17.8588(2)$ & $0.1334(1)$ & $0.5723(4)$ \\
\hline 1 & $3.0674(2)$ & $17.6723(5)$ & $0.1353(2)$ & $0.5743(9)$ \\
\hline
\end{tabular}

The dependencies of the hexagonal unit cell volume $\mathrm{V}$ and the lattice parameters $a, c$ on the Si content $x$ determined for all the $\mathrm{Ti}_{3}\left(\mathrm{Al}_{1-x} \mathrm{Si}_{x}\right) \mathrm{C}_{2}$ samples are shown in Figure 4 . In Figure $4 \mathrm{a}$, the deviation of the unit cell volume from Vegard's law (linear dependence with $x$ ) is also marked. It is worth noting that the largest difference in volume of about $1.3 \AA^{3}$ is visible for the $x=0.5$ sample.
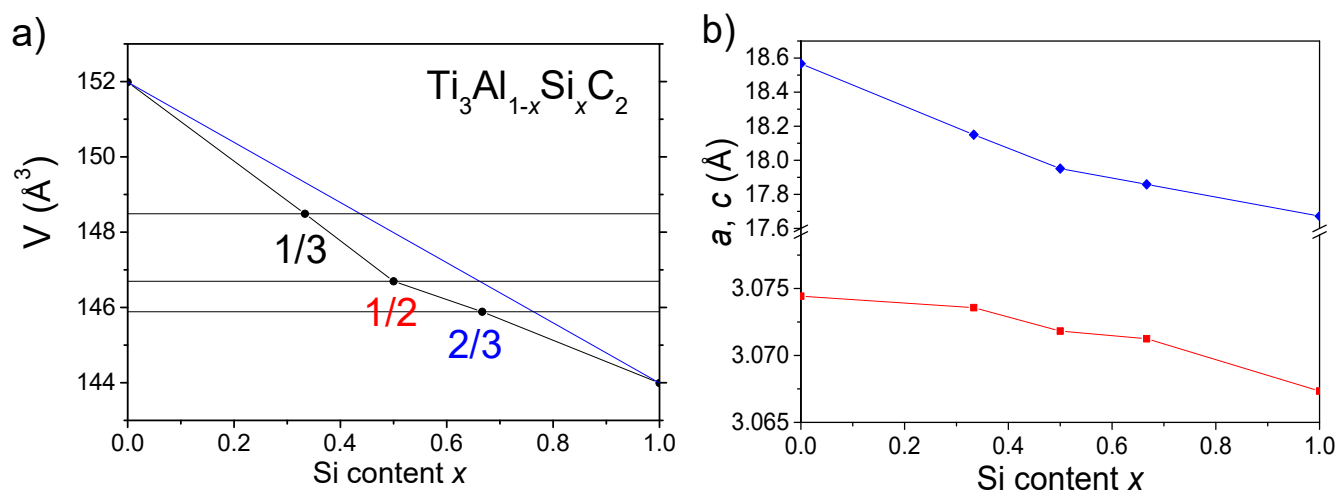

Figure 4. (a) Dependence of the unit cell volume $\mathrm{V}$ on the $\mathrm{Si}$ content $\mathrm{x}$ of the $\mathrm{Ti}_{3}\left(\mathrm{Al}_{1-x} \mathrm{Si}_{x}\right) \mathrm{C}_{2}$ samples (black dots). The blue solid line represents an assumed linear $\mathrm{V}(x)$ dependence. (b) Dependence of the unit cell parameters $a$ (red squares) and $c$ (blue diamonds) on the Si content $x$ of the $\mathrm{Ti}_{3}\left(\mathrm{Al}_{1-x} \mathrm{Si}_{x}\right) \mathrm{C}_{2}$ samples. Errors are comprised in symbol size.

A similar deviation from Vegard's law is seen for the lattice parameter $c(x)$ shown in Figure $4 b$. In contrast, the opposite curvature, a more linear character, and a much weaker dependence of the lattice parameter $a(x)$ was found. It is worth noting that the relative contraction of the $c$ parameter $(\Delta c / c)$ between the end compounds $\mathrm{Ti}_{3} \mathrm{AlC}_{2}$ and $\mathrm{Ti}_{3} \mathrm{SiC}_{2}$ is more than 20-times larger than the corresponding contraction $(\Delta a / a)$ for the $a$ parameter. Such anisotropic contraction can be expected for the layered type structure of these compounds when substitution of $\mathrm{Al}$ atoms forming separate layers along the $c$ direction of the hexagonal unit cell by much smaller Si atoms takes place.

\subsection{Microstructure Characterization}

In order to study the morphology of the materials, SEM and EDS measurements were carried out. A representative example image of the surface of the sample is presented in Figure 5 for the $\mathrm{Ti}_{3} \mathrm{Al}_{1 / 3} \mathrm{Si}_{2 / 3} \mathrm{C}_{2}$ material. It shows a flat structure decorated with small pores and ruptures typical for saw-cut materials synthetized with the hot-pressing method. The higher magnification (right panel) reveals the shape and size of the MAX phase grains, which is about 1 to $10 \mu \mathrm{m}$, similar to that reported by us in [19] for the border compound, $\mathrm{Ti}_{3} \mathrm{AlC}_{2}$. 


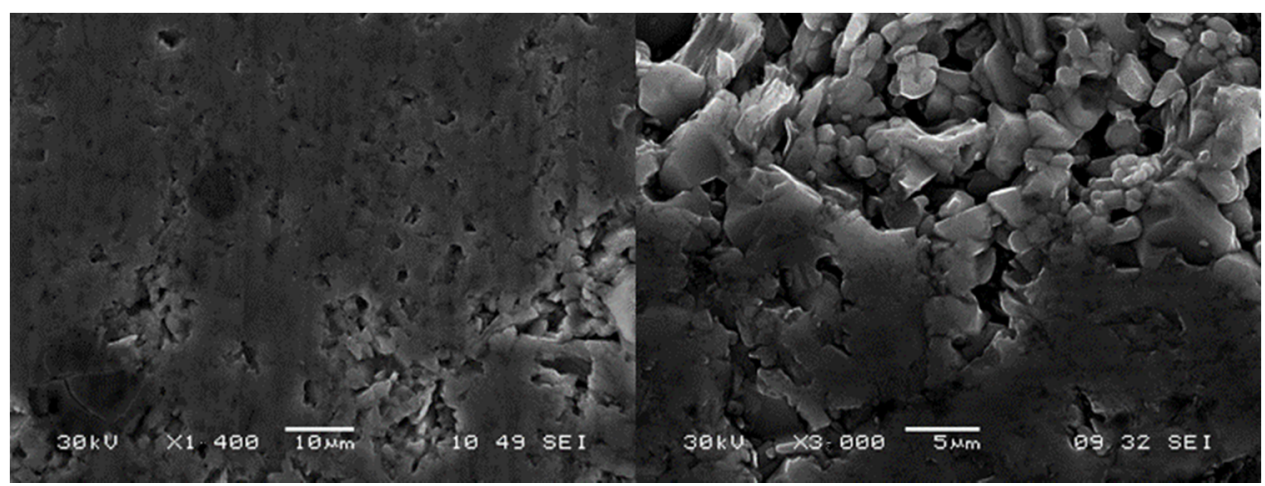

Figure 5. SEM images of the $\mathrm{Ti}_{3} \mathrm{Al}_{1 / 3} \mathrm{Si}_{2 / 3} \mathrm{C}_{2}$ material surface.

EDS spectra presented in Figure 6 show the intensities of the fluorescence lines of the constituent elements, which represent their relative content in the material. As can be expected, after normalization of the spectra to the maximum peak (Ti line), the silicon and alumina intensities grow/decrease with $x$. The example of a linear scan with EDS, shown in the insets, reveals an even distribution of elements, indicating good homogeneity of the material.

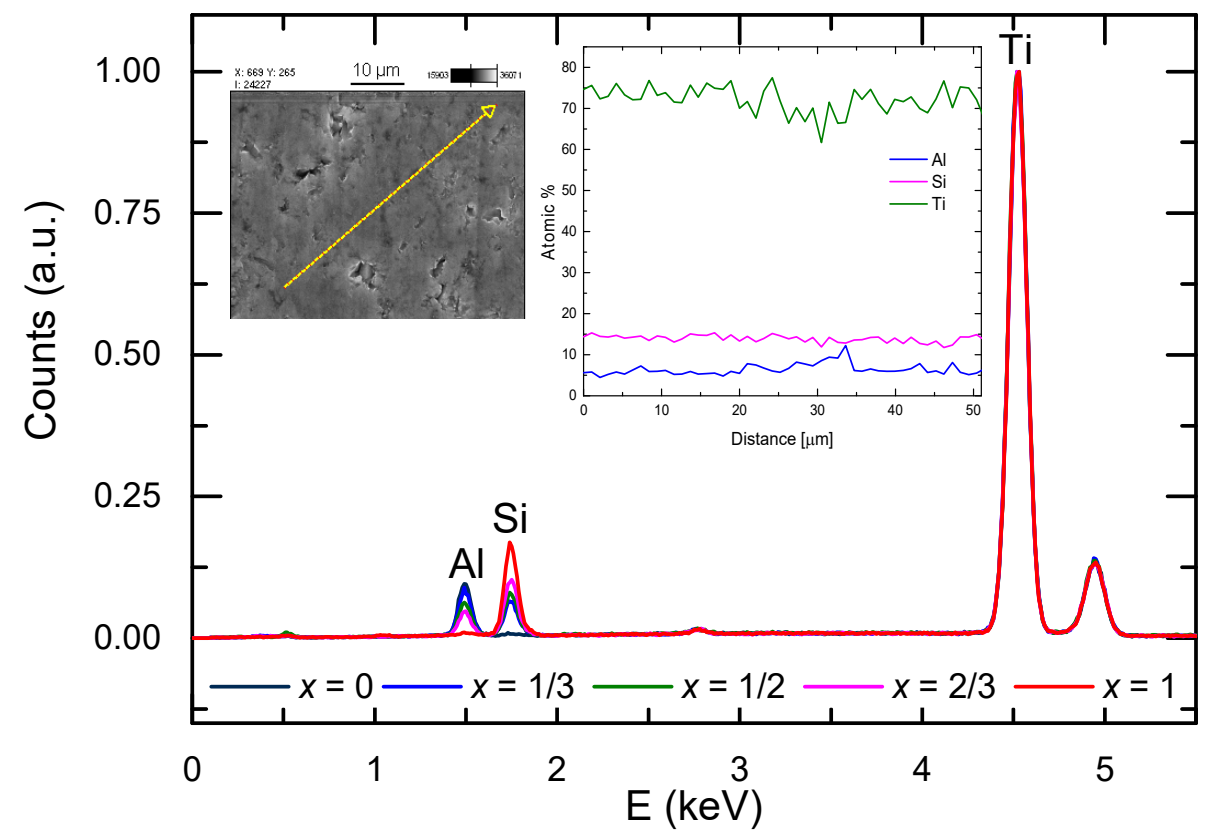

Figure 6. EDX spectra of the $\mathrm{Ti}_{3}\left(\mathrm{Al}_{1-\mathrm{x}} \mathrm{Si}_{\mathrm{x}}\right) \mathrm{C}_{2}$ samples. The insets show the SEM image of the surface of $\mathrm{Ti}_{3}\left(\mathrm{Al}_{1 / 3} \mathrm{Si}_{2 / 3}\right) \mathrm{C}_{2}$ (the arrow marks the line of the EDS scan) and the plot of concentrations of $\mathrm{Ti}$, $\mathrm{Al}$, and $\mathrm{Si}$ along this line.

\subsection{Heat Capacity}

Figure 7 shows the temperature dependence of the specific heat $\left(C_{p}\right)$ for $\mathrm{Ti}_{3} \mathrm{AlC}_{2}$ and $\mathrm{Ti}_{3} \mathrm{Al}_{1-x} \mathrm{Si}_{x} \mathrm{C}_{2}$ bulk compounds. One should note their close resemblance, but also clear differences at some temperature ranges. At high temperatures, the experimental points for all the compounds studied practically overlap, but they start to depart below $100 \mathrm{~K}$ (see top inset in Figure 7$)$. At the low temperature range $(T<10 \mathrm{~K})$, they show quite distinct differences (see bottom inset in Figure 7). The linear temperature dependence of the $C_{p} / T$ versus $T^{2}$ at the low temperature region corresponds to a Debye-like character of the lattice contribution. The coordinates of the extrapolated $y$-avis crossing points provide Sommerfeld coefficient values of the electronic contribution, revealing a metallic character of the MAX phase compounds studied. 


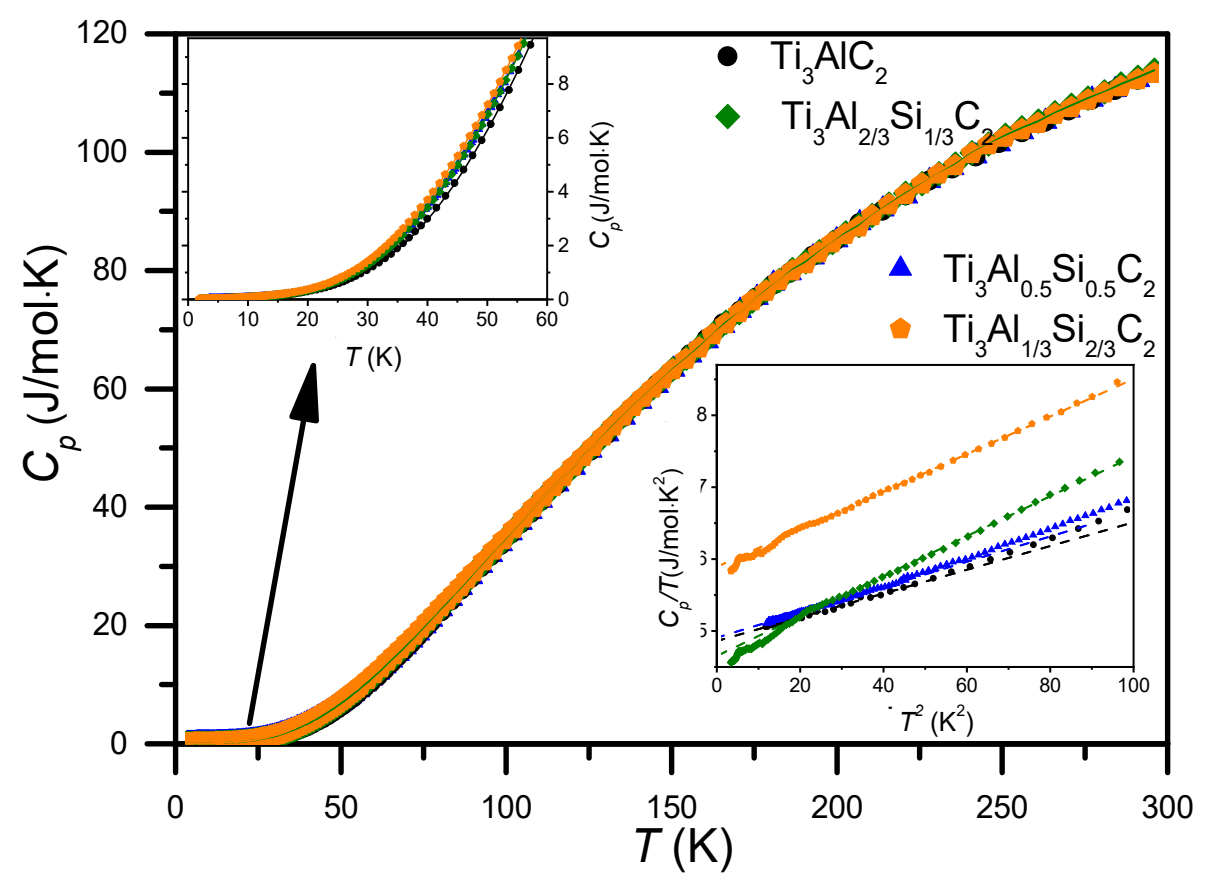

Figure 7. Temperature dependencies of the specific heat $\left(C_{p}\right)$ of $\mathrm{Ti}_{3} \mathrm{AlC}_{2}$, and $\mathrm{Ti}_{3} \mathrm{Al}_{1-x} \mathrm{Si}_{x} \mathrm{C}_{2}$ compounds. Fits (solid lines) represent Equation (1). The top inset shows the expanded low $T$ range. The bottom inset shows the low $T$ range as $C_{p} / T$ vs. $T^{2}$ plots. Linear fits to the data in the inset (dashed lines) were used to estimate the Debye temperature $\left(\Theta_{\mathrm{D}}\right)$ and the Sommerfeld coefficient $(\gamma)$ of the compounds.

The $C_{p}$ vs. $T$ dependence of the total specific heat of the nonmagnetic $\mathrm{Ti}_{3}(\mathrm{Si}, \mathrm{Al}) \mathrm{C}_{2}$ compounds can be approximated by phonon and electronic $\left(C_{e l}=\gamma T\right)$ contributions using the following expression $[36,37]$ :

$$
C_{p}=C_{p h}+C_{e l}=\frac{\mathrm{R}}{1-\alpha T}\left[9\left(\frac{T}{\Theta_{\mathrm{D}}}\right)^{3} \int_{0}^{\Theta_{\mathrm{D}} / T} \frac{\mathrm{x}^{4} \mathrm{e}^{\mathrm{x}}}{\left(\mathrm{e}^{\mathrm{x}}-1\right)^{2}} \mathrm{dx}+\sum_{\mathrm{i}} \frac{m_{i}\left(\frac{\Theta_{\mathrm{E}_{\mathrm{i}}}}{T}\right)^{2} \mathrm{e}^{\Theta_{\mathrm{E}_{\mathrm{i}}} / T}}{\left(\mathrm{e}^{\Theta_{\mathrm{E}_{\mathrm{i}}} / T}-1\right)^{2}}\right]+\gamma T,
$$

where $\Theta_{\mathrm{D}}$ is the Debye temperature, $\Theta_{\mathrm{E}_{\mathrm{i}}}$ are Einstein temperatures, $m_{i}$ are corresponding multiplicities for each individual optical branch, $\alpha$ stands for an anharmonic coefficient, $\gamma$ is an electronic specific heat (Sommerfeld) coefficient, and $\mathrm{R}$ is the gas constant. It is assumed that there are three acoustic modes in the compounds (described by the first term in square brackets) and 15 optical modes (described by the second one). In order to facilitate analysis, the summation over 15 independent optical branches was grouped into four branches of 3 or 6-fold multiplicity (this grouping was optimized by allowing for refinement of $m_{i}$ parameters during preliminary fitting of the formula and then rounding and fixing their values to the nearest natural number in the final fit).

To determine the approximated Debye temperatures $\left(\Theta_{D}^{1}\right)$ and Sommerfeld $(\gamma)$ coefficients conveniently, we can approximate Equation (4) at low $T$ by the sum of Debye $T^{3}$ law and $\gamma T$ linear term and fit linear parts of the low-temperature $C_{p} / T$ vs. $T^{2}$ plots of the same data (shown in the bottom inset in Figure 7. The values of the $\Theta_{D}^{1}$ and $\gamma$ parameters determined from them are listed in Table 3. One should note the very close values of $\Theta_{\mathrm{D}}^{1}$ and $\gamma$ parameters for the $\mathrm{Ti}_{3} \mathrm{AlC}_{2}$ and $\mathrm{Ti}_{3} \mathrm{Al}_{1 / 2} \mathrm{Si}_{1 / 2} \mathrm{C}_{2}$ compounds. Lower values of $\Theta_{\mathrm{D}}^{\mathrm{l}}$ for the $\mathrm{Ti}_{3} \mathrm{Al}_{2 / 3} \mathrm{Si}_{1 / 3} \mathrm{C}_{2}$ and $\mathrm{Ti}_{3} \mathrm{Al}_{1 / 3} \mathrm{Si}_{2 / 3} \mathrm{C}_{2}$ compounds indicate a softer lattice in them. The value of $\gamma$, which is noticeably larger for $\mathrm{Ti}_{3} \mathrm{Al}_{1 / 3} \mathrm{Si}_{2 / 3} \mathrm{C}_{2}$ than for the other compounds, correlates well with a higher DOS at Fermi level obtained for this compound (see Section 3.5). 
Table 3. The approximated Debye temperatures $\left(\Theta_{\mathrm{D}}^{1}\right)$ and Sommerfeld coefficients $(\gamma)$ determined from linear fits of the low temperature $C_{p} / T$ vs. $T^{2}$ plots $(T<7 \mathrm{~K})$ for the $\mathrm{Ti}_{3}\left(\mathrm{Al}_{1-x} \mathrm{Si}_{x}\right) \mathrm{C}_{2}$ compounds.

\begin{tabular}{ccccc}
\hline Parameter & $\mathbf{T i}_{3} \mathbf{A l C}_{2}$ & $\mathbf{T i}_{3} \mathbf{A l}_{\mathbf{2} / \mathbf{3}} \mathbf{S i}_{\mathbf{1} / \mathbf{3}} \mathbf{C}_{\mathbf{2}}$ & $\mathbf{T i}_{3} \mathbf{A l}_{\mathbf{1} / \mathbf{2}} \mathbf{S i}_{\mathbf{1} / \mathbf{2}} \mathbf{C}_{\mathbf{2}}$ & $\mathbf{T i}_{\mathbf{3}} \mathbf{A l}_{\mathbf{1} / \mathbf{3}} \mathbf{S i}_{\mathbf{2} / \mathbf{3}} \mathbf{C}_{\mathbf{2}}$ \\
\hline$\Theta_{\mathrm{D}}^{\mathrm{l}}(\mathrm{K})$ & $484.2 \pm 1.6$ & $412.1 \pm 0.4$ & $472.0 \pm 0.7$ & $420.6 \pm 0.5$ \\
\hline$\gamma\left(\mathrm{mJ} \cdot \mathrm{mol}^{-1} \cdot \mathrm{K}^{-2}\right)$ & $4.848 \pm 0.006$ & $4.653 \pm 0.005$ & $4.891 \pm 0.003$ & $5.893 \pm 0.005$ \\
\hline
\end{tabular}

From the fitting of Equation (4) to the whole $C_{p}$ vs. $T$ dependences from Figure 7 (in the refinement the Sommerfeld coefficients $\gamma$ were fixed at corresponding values from Table 3$)$, the Debye $\left(\Theta_{\mathrm{D}}\right)$, Einstein $\left(\Theta_{\mathrm{E}_{\mathrm{i}}}\right)$ temperature parameters and anharmonic coefficients $(\alpha)$ were also obtained for the $\mathrm{Ti}_{3} \mathrm{AlC}_{2}$ and $\mathrm{Ti}_{3} \mathrm{Al}_{1 / 2} \mathrm{Si}_{1 / 2} \mathrm{C}_{2}$ compounds; they are provided in Table 4 . One should note clearly lower values of the Debye temperatures $\left(\Theta_{\mathrm{D}}\right)$ from Table 4 (full temperature range fit) than from Table 3 (low temperature range fit). The latter can be regarded as representative, since the full temperature range fits a much larger error of the model, which involves many Einstein terms.

Table 4. The Debye $\left(\Theta_{\mathrm{D}}\right)$, Einstein $\left(\Theta_{\mathrm{E}_{\mathrm{i}}}\right)$ temperatures, and anharmonic coefficients $(\alpha)$ obtained from the fitting of Equation (4) to the $C_{p}$ vs. $T$ dependences from Figure 7 for $\mathrm{Ti}_{3} \mathrm{AlC}_{2}$ and $\mathrm{Ti}_{3} \mathrm{Al}_{1 / 2} \mathrm{Si}_{1 / 2} \mathrm{C}_{2}$ compounds. In the refinement, the Sommerfeld $(\gamma)$ coefficients were fixed at corresponding values from Table 3 and the multiplicities $m_{i}$ of the $\Theta_{\mathrm{E}_{\mathrm{i}}}$ parameters were set equal to 3, except of the $m_{3}$ (for $\Theta_{\mathrm{E}_{3}}$ ) which was set equal to 6 .

\begin{tabular}{ccc}
\hline Parameter & $\mathbf{T i}_{\mathbf{3}} \mathbf{A l C} \mathbf{2}_{\mathbf{2}}$ & $\mathbf{T i}_{\mathbf{3}} \mathbf{A l}_{\mathbf{1 / 2}} \mathbf{S i}_{\mathbf{1} / \mathbf{2}} \mathbf{C}_{\mathbf{2}}$ \\
\hline$\Theta_{\mathrm{D}}(\mathrm{K})$ & $396.2 \pm 4.1$ & $371.9 \pm 2.2$ \\
\hline$\Theta_{\mathrm{E}_{1}}(\mathrm{~K})$ & $299.6 \pm 3.4$ & $296.2 \pm 2.1$ \\
\hline$\Theta_{\mathrm{E}_{2}}(\mathrm{~K})$ & $459.2 \pm 4.8$ & $506.2 \pm 6.2$ \\
\hline$\Theta_{\mathrm{E}_{3}}(\mathrm{~K})$ & $652.9 \pm 3.4$ & $638.3 \pm 4.3$ \\
\hline$\Theta_{\mathrm{E}_{4}}(\mathrm{~K})$ & $1107 \pm 22$ & $1098 \pm 20$ \\
\hline$\alpha\left(10^{-5} \cdot \mathrm{K}^{-1}\right)$ & $9.1 \pm 1.0$ & $8.5 \pm 0.5$ \\
\hline
\end{tabular}

Figure 8 presents the variation of the experimental value of $\gamma$ with Si content, together with theoretical values obtained from calculations of the electronic density of states, presented in details in the subsequent paragraph.

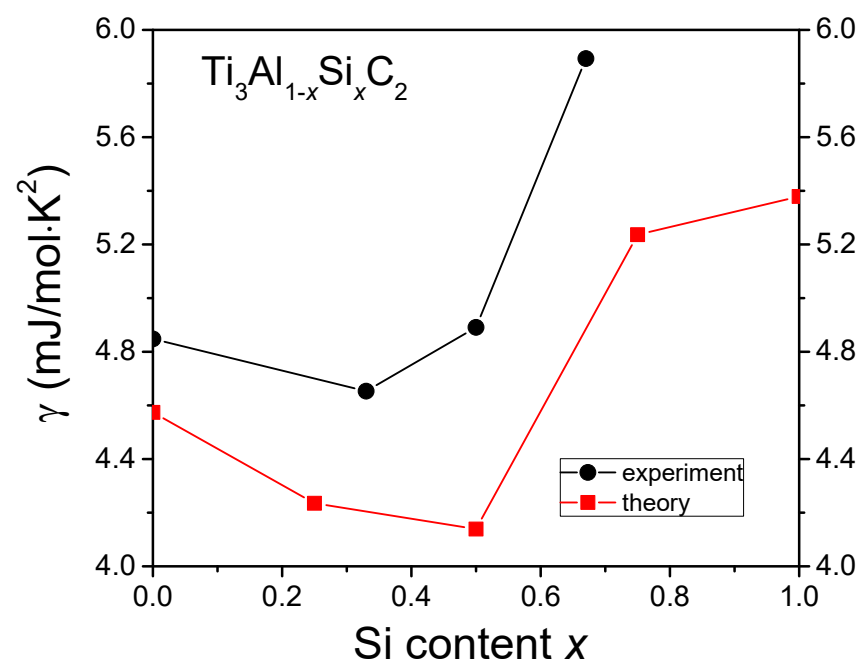

Figure 8. Dependence of the $\gamma$ values on the Si content obtained from the experiment and calculations. 
The experimental values are slightly higher than the theoretical ones, but the tendency with increasing Si doping is similar. It is worth noting that the high Si doping corresponds to a significantly increased $\gamma$.

\subsection{Electrical Resistivity and Magnetoresistance}

Measurements of the electrical resistivity were conducted with the four-point-probe method of the ACT (Alternating Current Transport) option of the QD PPMS (Quantum Design Physical Property Measurement System) apparatus in the temperature range from $4 \mathrm{~K}$ to $300 \mathrm{~K}$. The results are presented in Figure 9.

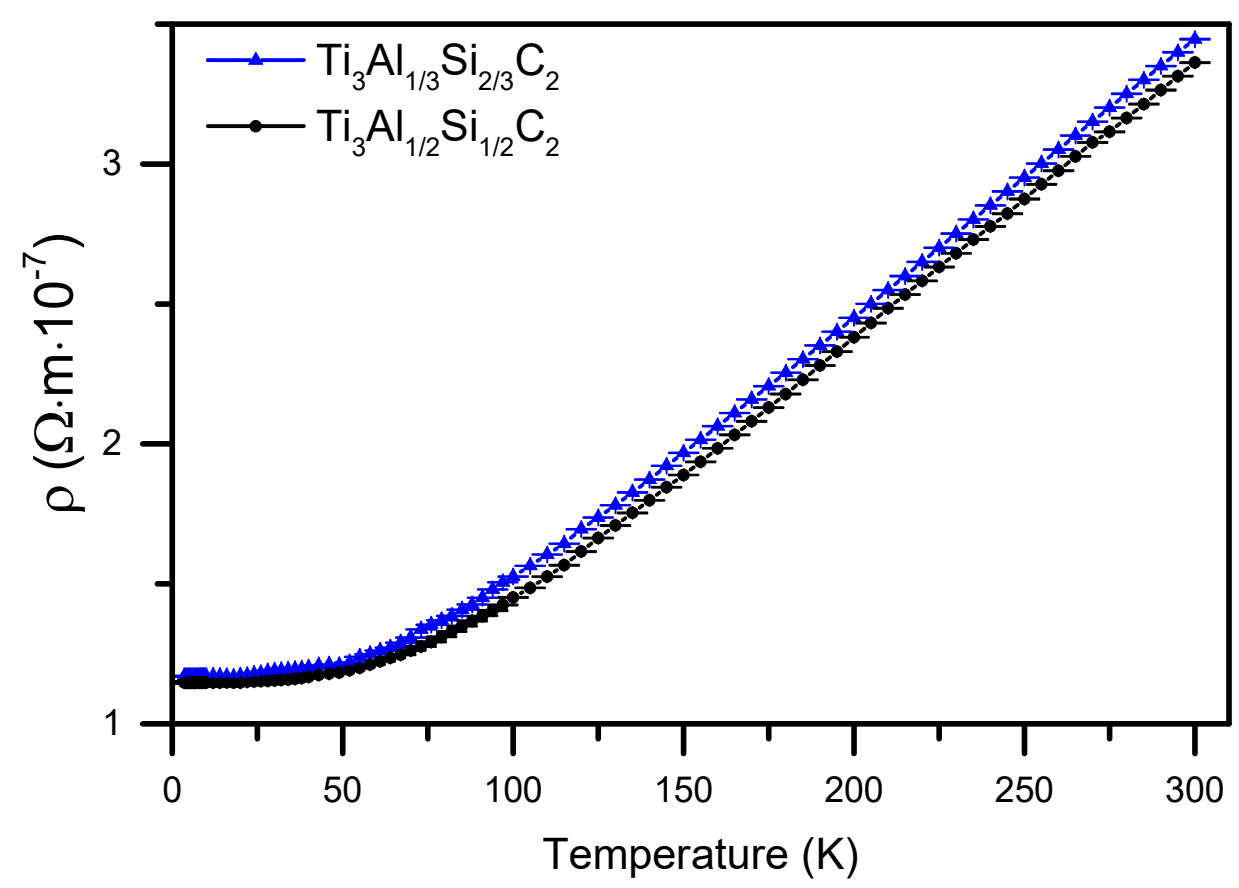

Figure 9. Electrical resistivity of $\mathrm{Ti}_{3}(\mathrm{Al}, \mathrm{Si}) \mathrm{C}_{2}$ materials as a function of temperature. Experimental points with error bars are marked.

They show a linear dependence down to the temperature of $100 \mathrm{~K}$, which reveals the metallic character of the materials. The residual resistivity, however, is relatively high and corresponds to a small Residual Resistivity Ratio (RRR), i.e., $R(293 K) / R(4 K)$, of 3. The low $\mathrm{RRR}$ is usually related to a substantial contribution of the scattering of electrical carriers at the crystal defects, comparable to that on phonons, dominating at high temperatures. Low RRR values have also been observed in our previous studies, [19] and by Finkel et al. [38], where for $\mathrm{Ti}_{3} \mathrm{AlC}_{2}$, a value of 1.95 was reported.

In order to shed more light on the electrical transport in the materials, measurements of the electrical resistivity have also been carried out at the applied magnetic field, to determine the magnetoresistance [39], i.e., the $\left(R_{H}-R_{0}\right) / R_{0}$ values at different temperatures. The results obtained are shown in Figure 10. 


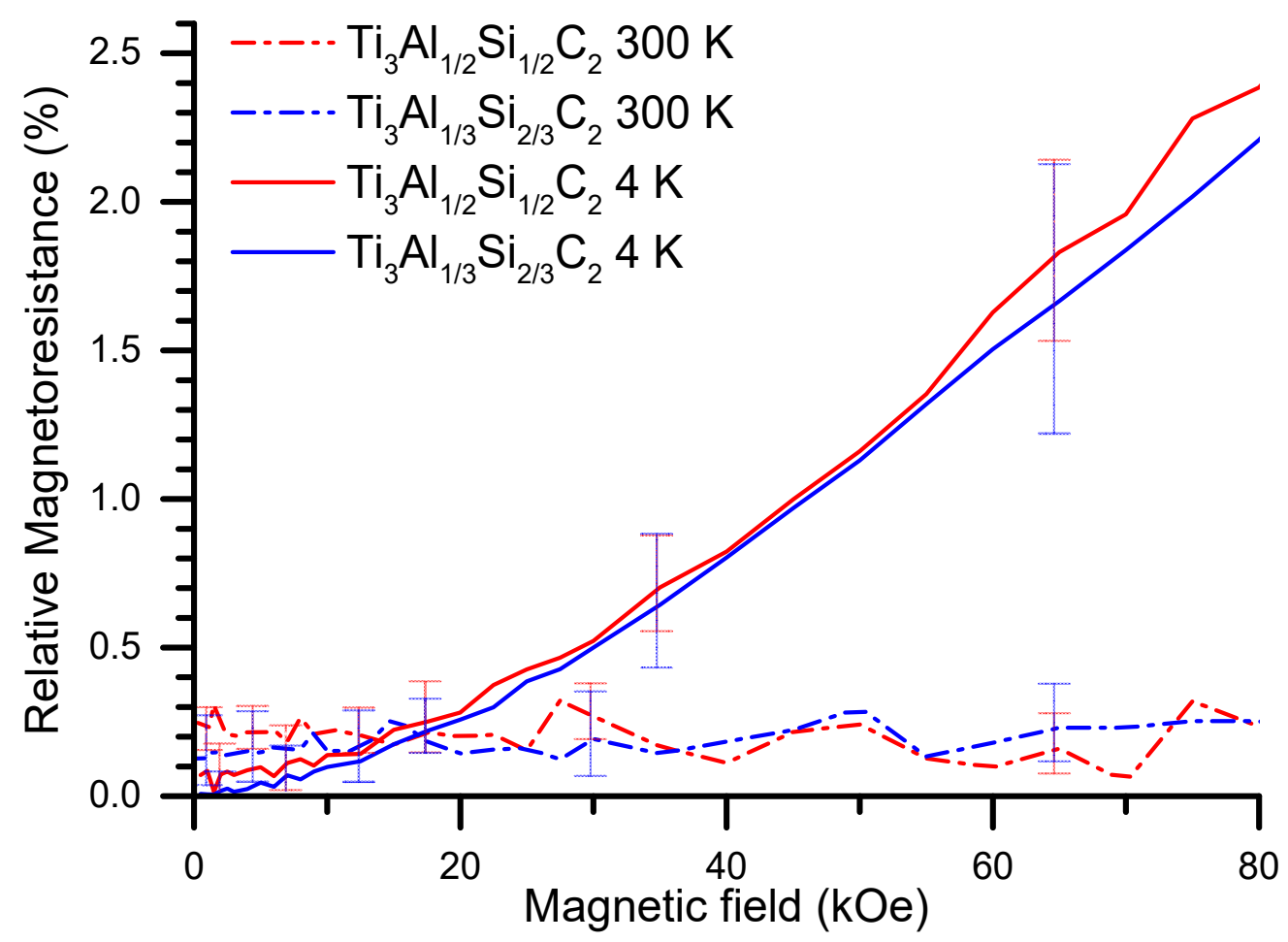

Figure 10. Magnetoresistance vs. magnetic field strength of the MAX phase materials at $300 \mathrm{~K}$ and $4 \mathrm{~K}$.

The magnetoresistance at $300 \mathrm{~K}$ is much smaller than at $4 \mathrm{~K}$ for the materials studied, as should be expected. The field dependencies of the magnetoresistance are found to fit well to a quadratic function, which indicates that the magnetoresistance effect in the MAX phase materials studied is dominated by contribution from open orbits. This is confirmed by the shape of the Fermi surface (Figure 11) derived from calculations [40] of the electronic structure for the end member compounds of the series, described in the paragraph below. It shows that the Fermi surface largely intersects the first Brillouin zone boundary along the [1] direction for $\mathrm{Ti}_{3} \mathrm{AlC}_{2}$ and, for $\mathrm{Ti}_{3} \mathrm{SiC}_{2}$, also in the directions within the perpendicular hexagonal plane. This brings about a large contribution of open orbits to the magnetoresistance, resulting in its quadratic dependence on the magnetic field.

\subsection{Density of States Calculations}

The calculations were done in the full potential WIEN 2k code [35] based on the density functional theory (DFT) [41,42] and the generalized gradient approximation (GGA) [43]. Table 5 presents the $\mathrm{Ti}_{3} \mathrm{AlC}_{2}$ structural data used, i.e., the lattice constants and Wyckoff position of atoms in the elementary cell. These parameters were obtained after minimization of total energy as a function of volumes and $c / a$ with starting values taken from [20]. All free parameters in site positions were adjusted according to force minimization. For calculations of $\mathrm{P} 63 / \mathrm{mmc}$ structure (ITC 194) with supercell, a $2 \times 2 \times 1$ and parameters listed in Table 5 was used. For the $\mathrm{Ti}_{3} \mathrm{Al}_{1 / 2} \mathrm{Si}_{1 / 2} \mathrm{C}_{2}$ sample, a $2 \times 2 \times 1$ superstructure within ICT 194 was adopted with shifting by $<00 \frac{1}{4}>$ vector and respective replacement of the Si and Al sites. We obtained the appropriate ICT 187 structure, which was used for the calculations. 

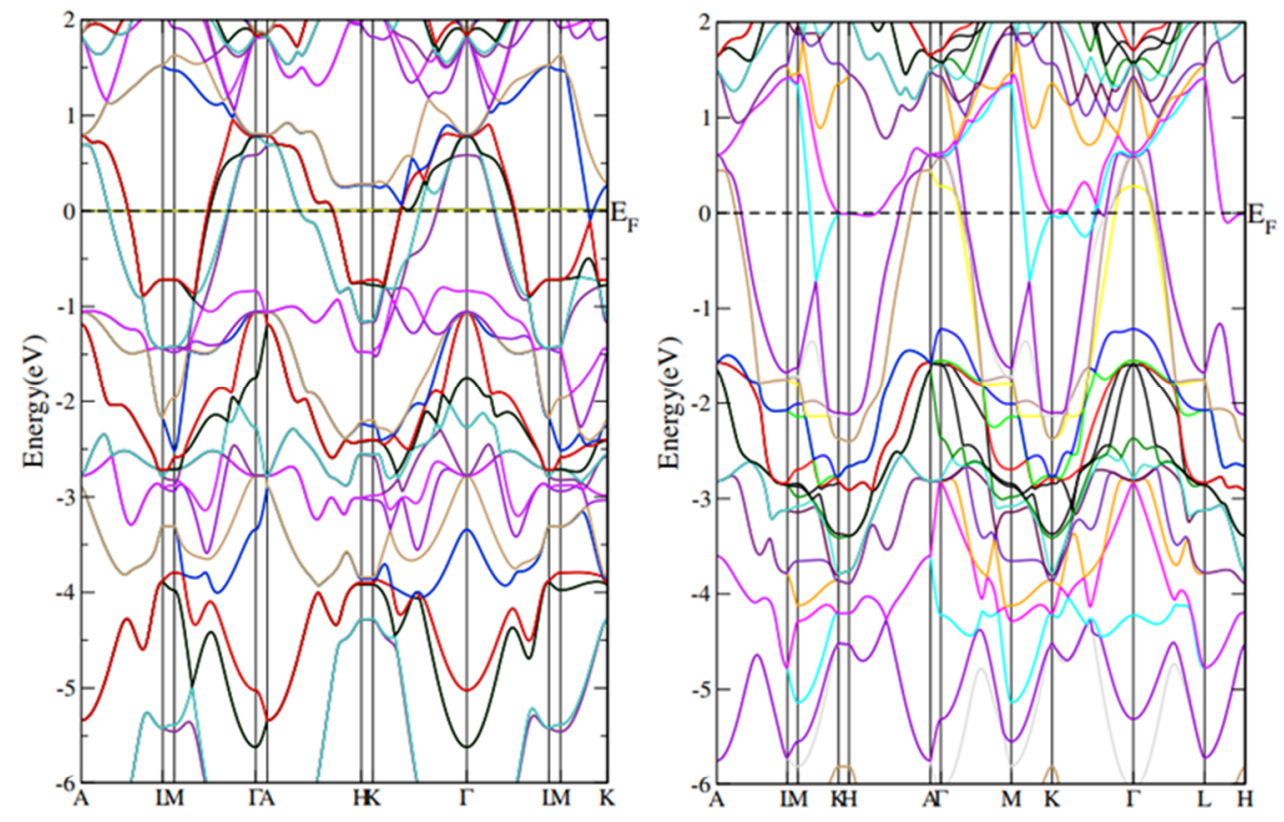

$\mathrm{Ti}_{3} \mathrm{AlC}_{2}$
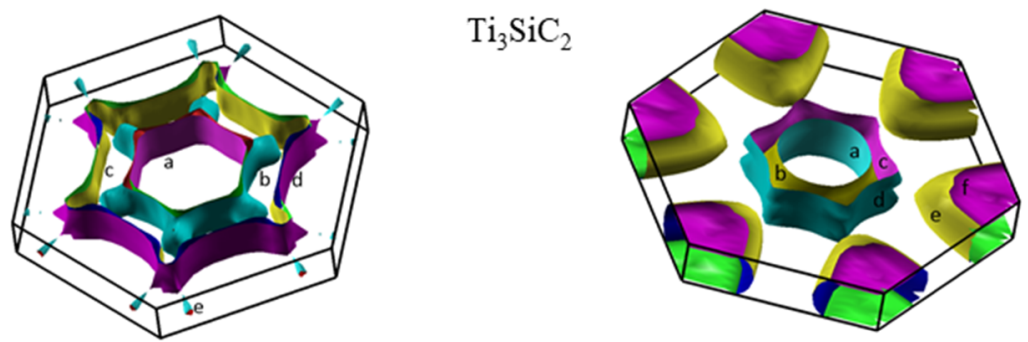

Figure 11. Band structures and Fermi surfaces of $\mathrm{Ti}_{3} \mathrm{AlC}_{2}$ (left) and $\mathrm{Ti}_{3} \mathrm{SiC}_{2}$ (right) for different bands. Vertical direction corresponds to the $<001>$ axis in the reciprocal lattice.

The reduced unit cell volume and the lattice constants calculated show a decrease with increasing Si content, as did the experimental values. However, the $a$ parameter shows a zig-zag dependence on $x$, with an excess value for the $\mathrm{Ti}_{3} \mathrm{Al}_{1 / 4} \mathrm{Si}_{1 / 4} \mathrm{C}_{2}$ sample. This feature is also visible in the unit cell volume dependence. To explain the possible origin of this effect, we also did the calculations for the $\mathrm{Ti}_{3} \mathrm{Al}_{1 / 2} \mathrm{Si}_{1 / 2} \mathrm{C}_{2}$ in the structure 187 with $\mathrm{Al}$ and $\mathrm{Si}$ in separate layers and got $a=3.0870 \AA$; however, but if we mix Si and Al within layers into the $2 \times 2 \times 1$ superstructure, this parameter is lower and amounts to $3.0517 \AA$. Thus, if the $\mathrm{Al} / \mathrm{Si}$ occupation in the $\mathrm{Ti}_{3} \mathrm{Al}_{1 / 4} \mathrm{Si}_{3 / 4} \mathrm{C}_{2}$ was fully random, which is possibly the case, we would probably get a lower $a$ parameter value, so our supercell model may not precisely describe the real material.

The calculated electronic structures of all the compounds $(x=0,1 / 4,1 / 2,3 / 4$ and 1$)$ show several bands crossing the Fermi level, which reveals their metallic character. The examples of the structure are shown for the end members of the series in Figure 11. The Fermi surface for an exemplary band of $\mathrm{Ti}_{3} \mathrm{AlC}_{2}$ was already presented in [19] and in the present paper complete Fermi surfaces for both compounds are shown, with the individual bands marked as a, b, c...

Usually the electrical properties of metallic-like materials relate the carrier density to the density of states at the Fermi energy, $\mathrm{DOS}\left(\mathrm{E}_{\mathrm{F}}\right)$. Thus, a considerable density of states at $\mathrm{E}_{\mathrm{F}}$ obtained for $\mathrm{Ti}_{3} \mathrm{AlC}_{2}$, much larger than that for aluminium metal, should result in a very good conductivity, which is obviously not the case. This is due to the fact that the most effective current carriers are those from s-band, which is the most delocalised, while the d-band electrons act as scatterers, decreasing the conductivity. For titanium metal, this effect is very dramatic and leads to forty times lower conductivity than that of copper, where the $3 \mathrm{~d}$ band is filled and has a negligible DOS at the Fermi level. This is very 
different from the situation in specific heat, where all the electrons at the Fermi level take part and the Sommerfeld coefficient of the electronic part is much higher for titanium than for copper, as mentioned above. A closer inspection of Figure 12 shows that the dominant densities of states at $\mathrm{E}_{\mathrm{F}}$ for Ti- 1 and Ti-2 sites are predominantly of d-type and are nearly two orders of magnitude higher than those of the p- or s-band. In contrast, for the $\mathrm{Al} / \mathrm{Si}$ site, the s-band DOS $\left(E_{\mathrm{F}}\right)$ is an order of magnitude higher than for both sites of Ti or C. It is also comparable to that in $\mathrm{Al}$ metal. Thus, the propagation of the electrical carriers provided by the $\mathrm{Al} / \mathrm{Si}$ sites is obstructed by the low s-like DOS( $\left.\mathrm{E}_{\mathrm{F}}\right)$ at the adjacent Ti and $\mathrm{C}$ sites, which results in high resistivity.

Table 5. Crystallographic information on the $\mathrm{Ti}_{3} \mathrm{AlC}_{2}, \mathrm{Ti}_{3} \mathrm{SiC}_{2}$, and $\mathrm{Ti}_{3} \mathrm{Al}_{1-\mathrm{x}} \mathrm{Si}_{\mathrm{x}} \mathrm{C}_{2}$ compounds.

\begin{tabular}{|c|c|c|c|c|c|c|}
\hline Compound & $\begin{array}{c}\text { Lattice } \\
\text { Parameters (A) }\end{array}$ & Atoms & $\begin{array}{l}\text { Wyckoff } \\
\text { Positions }\end{array}$ & $x$ & $\mathbf{y}$ & $\mathbf{Z}$ \\
\hline \multirow{4}{*}{$\mathrm{Ti}_{3} \mathrm{AlC}_{2}$} & \multirow{4}{*}{$\begin{array}{l}a=3.0547 \\
b=3.0547 \\
c=18.453\end{array}$} & Ti-1 & $2 a$ & 0 & 0 & 0 \\
\hline & & $\mathrm{Ti}-2$ & $4 f$ & $1 / 3$ & $2 / 3$ & 0.128 \\
\hline & & $\mathrm{Al}$ & $2 b$ & 0 & 0 & 0.25 \\
\hline & & C & $4 \mathrm{f}$ & $1 / 3$ & $2 / 3$ & 0.064 \\
\hline \multirow{8}{*}{$\mathrm{Ti}_{3} \mathrm{Al}_{3 / 4} \mathrm{Si}_{1 / 4} \mathrm{C}_{2}$} & \multirow{8}{*}{$\begin{array}{c}a=6.090 \\
b=6.090 \\
c=18.396\end{array}$} & Ti-1 & $6 g$ & $1 / 2$ & $1 / 2$ & $1 / 2$ \\
\hline & & Ti-2 & $2 a$ & 0 & 0 & $1 / 2$ \\
\hline & & Ti-3 & $12 \mathrm{k}$ & 0.331 & 0.166 & 0.129 \\
\hline & & $\mathrm{Ti}-4$ & $4 f$ & $1 / 3$ & $2 / 3$ & 0.127 \\
\hline & & $\mathrm{Si} / \mathrm{Al}$ & $2 b$ & $1 / 2$ & 0 & $1 / 4$ \\
\hline & & $\mathrm{Al} / \mathrm{Si}$ & $6 \mathrm{~h}$ & 0.498 & 0.502 & $1 / 4$ \\
\hline & & C-1 & $12 \mathrm{k}$ & 0.167 & 0.834 & 0.070 \\
\hline & & $\mathrm{C}-2$ & $4 \mathrm{f}$ & $1 / 3$ & $2 / 3$ & 0.57 \\
\hline \multirow{14}{*}{$\mathrm{Ti}_{3} \mathrm{Al}_{1 / 2} \mathrm{Si}_{1 / 2} \mathrm{C}_{2}$} & \multirow{14}{*}{$\begin{array}{c}a=6.103 \\
b=6.103 \\
c=18.064\end{array}$} & Ti-1 & $6 n$ & 0.5006 & 0.4999 & 0.246 \\
\hline & & Ti-2 & $2 g$ & 0 & 0 & 0.247 \\
\hline & & Ti-3 & $6 n$ & 0.167 & 0.833 & 0.117 \\
\hline & & $\mathrm{Ti}-4$ & $6 n$ & 0.834 & 0.166 & 0.378 \\
\hline & & Ti-5 & $2 \mathrm{~h}$ & $1 / 3$ & $2 / 3$ & 0.375 \\
\hline & & Ti-6 & $2 \mathrm{i}$ & $2 / 3$ & $1 / 3$ & 0.113 \\
\hline & & Si-1 & $3 \mathrm{j}$ & 0.490 & 0.510 & 0 \\
\hline & & $\mathrm{Si}-2$ & $1 b$ & 0 & 0 & $1 / 2$ \\
\hline & & Al.-1 & $1 a$ & 0 & 0 & 0 \\
\hline & & Al.-2 & $3 \mathrm{k}$ & 0.493 & 0.507 & $1 / 2$ \\
\hline & & C-1 & $6 n$ & 0.166 & 0.834 & 0.317 \\
\hline & & C-2 & $6 n$ & 0.833 & 0.167 & 0.176 \\
\hline & & C-3 & $2 \mathrm{~h}$ & $1 / 3$ & $2 / 3$ & 0.177 \\
\hline & & C-4 & $2 \mathrm{i}$ & $2 / 3$ & $1 / 3$ & 0.318 \\
\hline \multirow{8}{*}{$\mathrm{Ti}_{3} \mathrm{Al}_{1 / 4} \mathrm{Si}_{3 / 4} \mathrm{C}_{2}$} & \multirow{8}{*}{$\begin{array}{c}a=6.157 \\
b=6.157 \\
c=18.012\end{array}$} & Ti-1 & $6 g$ & $1 / 2$ & $1 / 2$ & $1 / 2$ \\
\hline & & Ti-2 & $2 a$ & 0 & 0 & $1 / 2$ \\
\hline & & Ti-3 & $12 \mathrm{k}$ & 0.335 & 0.168 & 0.132 \\
\hline & & Ti-4 & $4 f$ & $1 / 3$ & $2 / 3$ & 0.134 \\
\hline & & $\mathrm{Al}$ & $2 b$ & 0 & 0 & $1 / 4$ \\
\hline & & $\mathrm{Si}$ & $6 \mathrm{~h}$ & 0.504 & 0.496 & $1 / 4$ \\
\hline & & C-1 & $12 \mathrm{k}$ & 0.167 & 0.833 & 0.071 \\
\hline & & C-2 & $4 \mathrm{f}$ & $1 / 3$ & $2 / 3$ & 0.571 \\
\hline \multirow{4}{*}{$\mathrm{Ti}_{3} \mathrm{SiC}_{2}$} & \multirow{4}{*}{$\begin{array}{l}a=3.0422 \\
b=3.0422 \\
c=17.620\end{array}$} & Ti-1 & $2 a$ & 0 & 0 & 0 \\
\hline & & Ti-2 & $4 \mathrm{f}$ & $1 / 3$ & $2 / 3$ & 0.135 \\
\hline & & $\mathrm{Si}$ & $2 b$ & 0 & 0 & 0.25 \\
\hline & & C & $4 \mathrm{f}$ & $1 / 3$ & $2 / 3$ & 0 \\
\hline
\end{tabular}



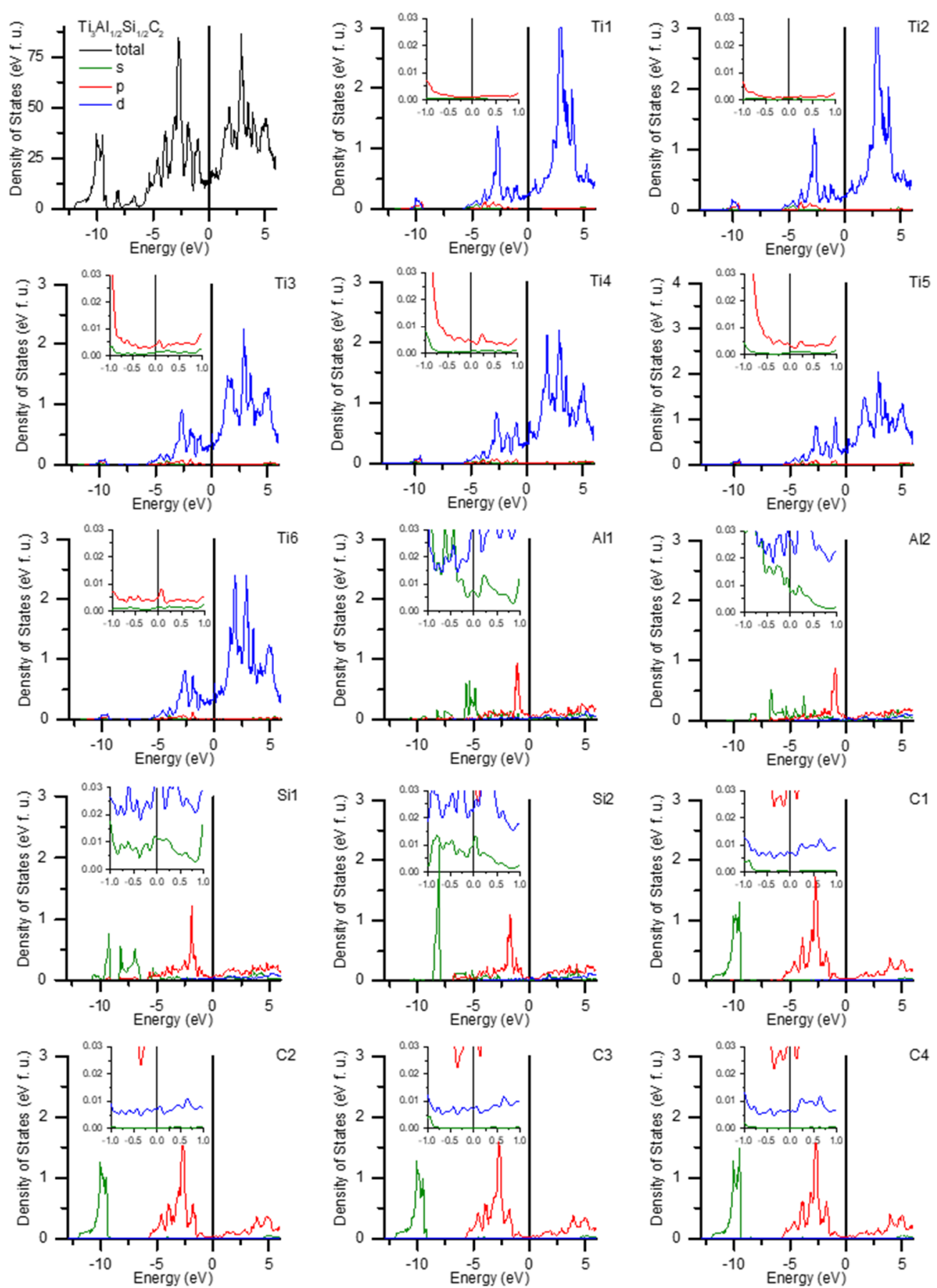

Figure 12. Calculated density of states of the $\mathrm{Ti}_{3} \mathrm{Al}_{1 / 2} \mathrm{Si}_{1 / 2} \mathrm{C}_{2}$ compound. Densities of states for $\mathrm{s}$ (green), $\mathrm{p}$ (red), and $\mathrm{d}$ (blue) sub-bands and the total density of states (black) are presented.

The magnetoresistance effect in a metal is approximately inversely proportional to the relaxation time of the electrical carriers, i.e., directly proportional to their mobility. From the above discussion, a mean free path of the order of interatomic distances can be anticipated, corresponding to a short relaxation time. This is consistent with the large residual resistivities and very low values of the magnetoresistance. In view of good crystallinity of the materials, as revealed in the X-ray diffraction study, the electron carrier scattering at the lattice defects can be excluded as the dominant mechanism. Considering quasi two-dimensionality of the materials, the mechanism related to the Anderson localization should also be taken into account [44-46]. However, its verification is beyond the scope of this work. The picture of the electronic properties drawn from the above presented and 
discussed results is consistent with a relatively small electronic contribution to the specific heat, indicating a limited population of delocalised electrons at the Fermi level taking part in the electrical and thermal phenomena.

\section{Conclusions}

The study carried out on the $\mathrm{Ti}_{3}(\mathrm{Al}, \mathrm{Si}) \mathrm{C}_{2}$ materials synthesized with hot pressing from $\mathrm{Ti}_{3} \mathrm{AlC}_{2}$ and $\mathrm{Ti}_{3} \mathrm{SiC}_{2}$ powders obtained with self-propagating high-temperature synthesis revealed their good crystallinity, as deduced from narrow lines of their X-ray diffraction patterns.

Measurements of specific heat delivered the Debye temperatures and Sommerfeld coefficient values, which show slight variations with Si doping with decreasing tendency for the Debye temperatures and an increase for the Sommerfeld coefficient. A small residual resistivity ratio of 3 was obtained from the measurements. The magnetoresistance at $4 \mathrm{~K}$ was an order of magnitude larger than at $300 \mathrm{~K}$ and was found to exhibit a quadratic field dependence. This reveals a dominant contribution coming from open electronic orbits and is consistent with the calculated shape of the Fermi surface.

From a detailed look at the crystallographic and electronic structure, specific heat, electrical resistivity, and magnetoresistance of the materials, a novel result of the present contribution could be drawn. It relies on the explanation of the relatively high resistivity of MAX phases with the disparity of the local densities of states at the Fermi level derived for individual sites and orbitals of constituent elements. This concerns the densities of s-electrons, which contribute the most to the electrical conductivity and are provided there mainly by aluminium and silicon. Neighbouring titanium atoms with very low s-electron densities, but very high d-electron densities act as scatterers for the electrical carriers. This draws a consistent picture of the electronic and thermal properties of the MAX phase materials studied and the intrinsic character of their high residual resistivity.

Author Contributions: Conceptualization: J.L., L.C. and C.K.; Methodology: C.K., J.M.M., L.C., K.G., K.W., J.P., and T.S.; Software: W.T.; Validation: C.K., K.G. and T.S.; Formal Analysis: C.K., J.P.; Investigation: K.G., J.M.M., J.P., J.J., T.S., K.W.; Resources: L.C., K.W.; Data Curation: K.G.; Writing—Original Draft Preparation: K.G., C.K., J.P., W.T., I.U., L.C.; Writing-Review \& Editing: K.G., C.K., J.P., W.T., I.U., L.C.; Visualization: K.G., J.M.M., J.P.; Supervision: C.K., I.U. and J.L.; Project Administration: C.K.; Funding Acquisition: J.L. and C.K. All authors have read and agreed to the published version of the manuscript.

Funding: This work was supported by the Polish National Science Centre (Project No. 2013/11/B/ ST5/02275). Partial support within subvention of the Polish Ministry of Education and Science to the Faculty of Physics and Applied Computer Science, AGH UST, is acknowledged.

Institutional Review Board Statement: Not applicable.

Informed Consent Statement: Not applicable.

Data Availability Statement: The data presented in this study are available on request from the corresponding author.

Conflicts of Interest: The authors declare no conflict of interest.

\section{References}

1. Barsoum, M.W. The $\mathrm{M}_{\mathrm{N}+1} \mathrm{AX}_{\mathrm{N}}$ Phases: A New Class of Solids: Thermodynamically Stable Nanolaminates. Prog. Solid State Chem. 2000, 28, 201-281. [CrossRef]

2. Eklund, P.; Beckers, M.; Jansson, U.; Högberg, H.; Hultman, L. The $\mathrm{M}_{\mathrm{n}+1} \mathrm{AX}$ Phases: Materials Science and Thin-Film Processing. Thin Solid Films 2010, 518, 1851-1878. [CrossRef]

3. Low, I.-M. An Overview of Parameters Controlling the Decomposition and Degradation of Ti-Based $M_{n+1} A X_{n}$ Phases. Materials 2019, 12, 473. [CrossRef]

4. Jeitschko, W.; Nowotny, H.; Benesovsky, F. Kohlenstoffhaltige ternäre Verbindungen (H-Phase). Mon. Für Chem. Verwandte Teile Anderer Wiss. 1963, 94, 672-676. [CrossRef]

5. Barsoum, M.W. MAX Phases: Properties of Machinable Ternary Carbides and Nitrides; Wiley-VCH Verlag GmbH \& Co. KGaA: Weinheim, Germany, 2013.

6. Barsoum, M.W.; Radovic, M. MAX Phases: Bridging the Gap between Metals and Ceramics. Am. Ceram. Soc. Bull. $2013,92,20-27$. 
7. Barsoum, M.W.; El-Raghy, T.; Ali, M. Processing and Characterization of $\mathrm{Ti}_{2} \mathrm{AlC} \mathrm{Ti}_{2} \mathrm{AlN}$, and $\mathrm{Ti}_{2} \mathrm{AlC}_{0.5} \mathrm{~N}_{0.5} \cdot$ Metall. Mater. Trans. A 2000, 31, 1857-1865. [CrossRef]

8. Tzenov, N.V.; Barsoum, M.W. Synthesis and Characterization of $\mathrm{Ti}_{3} \mathrm{AlC}_{2}$. J. Am. Ceram. Soc. 2000, 83, 825-832. [CrossRef]

9. Ying, G.; He, X.; Li, M.; Li, Y.; Du, S. Synthesis and Mechanical Properties of Nano-Layered Composite. J. Alloys Compd. 2010, 506, 734-738. [CrossRef]

10. Chen, W.; Tang, J.; Shi, X.; Ye, N.; Yue, Z.; Lin, X. Synthesis and Formation Mechanism of High-Purity Ti ${ }_{3} \mathrm{AlC}_{2}$ Powders by Microwave Sintering. Int. J. Appl. Ceram. Technol. 2020, 17, 778-789. [CrossRef]

11. Sobolev, K.V.; Kolincio, K.K.; Emelyanov, A.; Mielewczyk-Gryń, A.; Gazda, M.; Roman, M.; Pazniak, A.; Rodionova, V. Evolution of Magnetic and Transport Properties in $\left(\mathrm{Cr}_{1-\mathrm{x}} \mathrm{Mn}_{\mathrm{x}}\right)_{2} \mathrm{AlC}$ MAX-Phase Synthesized by Arc Melting Technique. J. Magn. Magn. Mater. 2020, 493, 165642. [CrossRef]

12. Berger, O. The Correlation between Structure, Multifunctional Properties and Application of PVD MAX Phase Coatings. Part III. Multifunctional Applications. Surf. Eng. 2020, 36, 303-325. [CrossRef]

13. Lane, N.J.; Naguib, M.; Lu, J.; Hultman, L.; Barsoum, M.W. Structure of a New Bulk $\mathrm{Ti}_{5} \mathrm{Al}_{2} \mathrm{C}_{3} \mathrm{MAX}$ Phase Produced by the Topotactic Transformation of $\mathrm{Ti}_{2}$ AlC. J. Eur. Ceram. Soc. 2012, 32, 3485-3491. [CrossRef]

14. Zhou, W.; Mei, B.; Zhu, J. Effect of Tin on the Reaction Synthesis of Ternary Carbide $\mathrm{Ti}_{3} \mathrm{AlC}_{2}$. J. Wuhan Univ. Technol. Mater Sci Ed. 2009, 24, 283-286. [CrossRef]

15. Zhou, W.; Mei, B.; Zhu, J.; Hong, X. Synthesis of High-Purity $\mathrm{Ti}_{3} \mathrm{SiC}_{2}$ and $\mathrm{Ti}_{3} \mathrm{AlC}_{2}$ by Spark Plasma Sintering (SPS) Technique. J. Mater. Sci. 2005, 40, 2099-2100. [CrossRef]

16. Yang, C.; Jin, S.Z.; Liang, B.Y.; Jia, S.S. Low-Temperature Synthesis of High-Purity $\mathrm{Ti}_{3} \mathrm{AlC}_{2}$ by MA-SPS Technique. J. Eur. Ceram. Soc. 2009, 29, 181-185. [CrossRef]

17. Garbiec, D.; Leshchynsky, V.; Colella, A.; Matteazzi, P.; Siwak, P. Structure and Deformation Behavior of Ti-SiC Composites Made by Mechanical Alloying and Spark Plasma Sintering. Materials 2019, 12, 1276. [CrossRef]

18. Chlubny, L.; Lis, J.; Kapusta, C.; Zientara, D.; Chabior, K.; Chachlowska, P. Phase Evolution Phenomenon During Hot Pressing of the SHS Obtained $\mathrm{Ti}_{3} \mathrm{AlC}_{2}$ Precursors Powders. In Additive Manufacturing and Strategic Technologies in Advanced Ceramics; Shimamura, K., Kirihara, S., Akedo, J., Ohji, T., Naito, K., Eds.; John Wiley \& Sons, Inc.: Hoboken, NJ, USA, 2016 ; pp. $219-228$. ISBN 978-1-119-23601-6.

19. Goc, K.; Prendota, W.; Chlubny, L.; Straczek, T.; Tokarz, W.; Chachlowska, P.B.; Chabior, K.W.; Bućko, M.M.; Przewoźnik, J.; Lis, J. Structure, Morphology and Electrical Transport Properties of the $\mathrm{Ti}_{3} \mathrm{AlC}_{2}$ Materials. Ceram. Int. 2018, 44, 18322-18328. [CrossRef]

20. Wang, X.H.; Zhou, Y.C. Layered Machinable and Electrically Conductive Influence of Precursors Stoichiometry on SHS Synthesis of $\mathrm{Ti}_{2} \mathrm{AlC}$ Powders and Influence of Precursors Stoichiometry on SHS Synthesis of $\mathrm{Ti}_{3} \mathrm{AlC}_{2}$ Powders Ceramics: A Review. J. Mater. Sci. Technol. 2010, 26, 385-416. [CrossRef]

21. Yeh, C.L.; Yang, W.J. Formation of MAX Solid Solutions $(\mathrm{Ti}, \mathrm{V})_{2} \mathrm{AlC}$ and $(\mathrm{Cr}, \mathrm{V})_{2} \mathrm{AlC}$ with $\mathrm{Al}_{2} \mathrm{O}_{3}$ Addition by SHS Involving Aluminothermic Reduction. Ceram. Int. 2013, 39, 7537-7544. [CrossRef]

22. Chlubny, L.; Lis, J.; BuĐko, M.M. Densification of SHS Obtained Ti ${ }_{2}$ AlC Active Precursor Powder by Hot Pressing Method. In Processing and Properties of Advanced Ceramics and Composites VII; John Wiley \& Sons, Ltd.: Hoboken, NJ, USA, 2015; pp. 203-212. ISBN 978-1-119-18386-0.

23. Chlubny, L.; Lis, J.; Chabior, K.; Chachlowska, P.; Kapusta, C. Processing And Properties of MAX Phases-Based Materials Using SHS Technique. Arch. Metall. Mater. 2015, 60. [CrossRef]

24. Lis, J.; Chlubny, L.; Witulska, K.; Borowiak, P.; Kozak, K.; Misztal, A.; Czajkowska, O. SHS of Ti $3 \mathrm{SiC}_{2}$-Based Materials in the Ti-Si-C System: Impact of Silicon Excess. Int. J. Self Propagating High Temp. Synth. 2019, 28, 262-265. [CrossRef]

25. Chlubny, L.; Lis, J.; Bućko, M.M. Sintering and Hot-Pressing of Ti ${ }_{2} \mathrm{AlC}$ Obtained by SHS Process. Adv. Sci. Technol. 2010, 63, 282-286. [CrossRef]

26. Biswas, A.; Sengupta, A.; Rajput, U.; Singh, S.K.; Antad, V.; Hossain, S.M.; Parmar, S.; Rout, D.; Deshpande, A.; Nair, S.; et al. Growth, Properties, and Applications of Pulsed Laser Deposited Nanolaminate $\mathrm{Ti}_{3} \mathrm{AlC}_{2}$ Thin Films. Phys. Rev. Appl. 2020, 13, 044075. [CrossRef]

27. Yu, W.; Li, S.; Sloof, W.G. Microstructure and Mechanical Properties of a $\mathrm{Cr}_{2} \mathrm{Al}(\mathrm{Si}) \mathrm{C}$ Solid Solution. Mater. Sci. Eng. A 2010, 527, 5997-6001. [CrossRef]

28. Bei, G.P.; Gauthier-Brunet, V.; Tromas, C.; Dubois, S. Synthesis, Characterization, and Intrinsic Hardness of Layered Nanolaminate $\mathrm{Ti}_{3} \mathrm{AlC}_{2}$ and $\mathrm{Ti}_{3} \mathrm{Al}_{0.8} \mathrm{Sn}_{0.2} \mathrm{C}_{2}$ Solid Solution. J. Am. Ceram. Soc. 2012, 95, 102-107. [CrossRef]

29. Radovic, M.; Barsoum, M.W.; Ganguly, A.; Zhen, T.; Finkel, P.; Kalidindi, S.R.; Lara-Curzio, E. On the Elastic Properties and Mechanical Damping of $\mathrm{Ti}_{3} \mathrm{SiC}_{2}, \mathrm{Ti}_{3} \mathrm{GeC}_{2}, \mathrm{Ti}_{3} \mathrm{Si}_{0.5} \mathrm{Al}_{0.5} \mathrm{C}_{2}$ and $\mathrm{Ti}_{2} \mathrm{AlC}$ in the $300-1573 \mathrm{~K}$ Temperature Range. Acta Mater. 2006, 54, 2757-2767. [CrossRef]

30. Mockute, A.; Dahlqvist, M.; Emmerlich, J.; Hultman, L.; Schneider, J.M.; Persson, P.O.Å.; Rosen, J. Synthesis and Ab Initio Calculations of Nanolaminated (Cr,Mn) ${ }_{2}$ AlC Compounds. Phys. Rev. B 2013, 87, 094113. [CrossRef]

31. Gao, H.; Benitez, R.; Son, W.; Arroyave, R.; Radovic, M. Structural, Physical and Mechanical Properties of $\mathrm{Ti}_{3}\left(\mathrm{Al}_{1-\mathrm{x}} \mathrm{Si}_{\mathrm{x}}\right) \mathrm{C}_{2} \mathrm{Solid}$ Solution with $\mathrm{X}=0-1$. Mater. Sci. Eng. A 2016, 676, 197-208. [CrossRef]

32. Wang, H.; Han, H.; Yin, G.; Wang, C.-Y.; Hou, Y.-Y.; Tang, J.; Dai, J.-X.; Ren, C.-L.; Zhang, W.; Huai, P. First-Principles Study of Vacancies in $\mathrm{Ti}_{3} \mathrm{SiC}_{2}$ and $\mathrm{Ti}_{3} \mathrm{AlC}_{2}$. Materials 2017, 10, 103. [CrossRef] 
33. Ng, W.H.K.; Gnanakumar, E.S.; Batyrev, E.; Sharma, S.K.; Pujari, P.K.; Greer, H.F.; Zhou, W.; Sakidja, R.; Rothenberg, G.; Barsoum, M.W.; et al. The $\mathrm{Ti}_{3} \mathrm{AlC}_{2} \mathrm{MAX}$ Phase as an Efficient Catalyst for Oxidative Dehydrogenation of N-Butane. Angew. Chem. Int. Ed. 2018, 57, 1485-1490. [CrossRef] [PubMed]

34. Rietveld, H.M. A Profile Refinement Method for Nuclear and Magnetic Structures. J. Appl. Crystallogr. 1969, 2, 65-71. [CrossRef]

35. Peter, B.; Karlheinz, S.; Madsen, G.K.H.; Dieter, K.; Joachim, L.; Robert, L.; Fabien, T.; Laurence, D.M. WIEN2k-An Augmented Plane Wave + Local Orbitals Program for Calculating Crystal Properties; Vienna University of Technology: Vienna, Austria, 2018; ISBN 3-9501031-1-2.

36. Szytuła, A.; Kaczorowski, D.; Szewczyk, A.; Gutowska, M.; Piekarz, P. Multiple Magnetic Phase Transitions in $\mathrm{Tb}_{3} \mathrm{Cu}_{4} \mathrm{Si}_{4}$. J. Phys. Condens. Matter 2007, 19, 246225. [CrossRef]

37. Ashcroft, N.W.; Mermin, N.D. Solid State Physics; Harcourt College Publisher: New York, NY, USA, 1976.

38. Finkel, P.; Barsoum, M.W.; Hettinger, J.D.; Lofland, S.E.; Yoo, H.I. Low-Temperature Transport Properties of Nanolaminates $\mathrm{Ti}_{3} \mathrm{AlC}_{2}$ and $\mathrm{Ti}_{4} \mathrm{AlN}_{3}$. Phys. Rev. B 2003, 67, 235108. [CrossRef]

39. Sondheimer, E.H.; A, B.; Wilson, A.H.; S, F.R. The Theory of the Magneto-Resistance Effects in Metals. Proc. R. Soc. Lond. A 1947, 190, 435-455. [CrossRef]

40. Kokalj, A. Computer Graphics and Graphical User Interfaces as Tools in Simulations of Matter at the Atomic Scale. Comput. Mater. Sci. 2003, 28, 155-168. [CrossRef]

41. Hohenberg, P.; Kohn, W. Inhomogeneous Electron Gas. Phys. Rev. 1964, 136, B864-B871. [CrossRef]

42. Kohn, W.; Sham, L.J. Self-Consistent Equations Including Exchange and Correlation Effects. Phys. Rev. 1965, 140, A1133-A1138. [CrossRef]

43. Perdew, J.P.; Burke, K.; Ernzerhof, M. Generalized Gradient Approximation Made Simple. Phys. Rev. Lett. 1996, 77, 3865-3868. [CrossRef]

44. Lubatsch, A.; Frank, R. Self-Consistent Quantum Field Theory for the Characterization of Complex Random Media by Short Laser Pulses. Phys. Rev. Res. 2020, 2, 013324. [CrossRef]

45. Vollhardt, D.; Wölfle, P. Diagrammatic, Self-Consistent Treatment of the Anderson Localization Problem in $\$ d \backslash$ ensuremath $\{\backslash$ le $\} 2 \$$ Dimensions. Phys. Rev. B 1980, 22, 4666-4679. [CrossRef]

46. Vollhardt, D.; Wölfle, P. Anderson Localization in \$d< 2\$ Dimensions: A Self-Consistent Diagrammatic Theory. Phys. Rev. Lett. 1980, 45, 842-846. [CrossRef] 